\title{
An Archaeological Assessment of the San Antonio 201 Wastewater Treatment Project
}

Anne A. Fox

Follow this and additional works at: https://scholarworks.sfasu.edu/ita

Part of the American Material Culture Commons, Archaeological Anthropology Commons, Environmental Studies Commons, Other American Studies Commons, Other Arts and Humanities Commons, Other History of Art, Architecture, and Archaeology Commons, and the United States History Commons

Tell us how this article helped you.

This Article is brought to you for free and open access by the Center for Regional Heritage Research at SFA ScholarWorks. It has been accepted for inclusion in Index of Texas Archaeology: Open Access Gray Literature from the Lone Star State by an authorized editor of SFA ScholarWorks. For more information, please contact cdsscholarworks@sfasu.edu. 
An Archaeological Assessment of the San Antonio 201 Wastewater Treatment Project

\section{Creative Commons License}

\section{(c) (1) \&}

This work is licensed under a Creative Commons Attribution-NonCommercial 4.0 International License 


\title{
AN ARCHAEOLOGICAL ASSESSMENT OF THE SAN ANTONIO 201 WASTEWATER TREATMENT PROJECT
}

\author{
Anne A. Fox
}

Center for Archaeological Research The University of Texas at San Antonio Archaeological Survey Report, No. 41 1977 
AN ARCHAEOLOGICAL ASSESSMENT OF

THE SAN ANTONIO 201 WASTEWATER TREATMENT PROJECT

Anne A. Fox

Center for Archaeological Research The University of Texas at San Antonio Archaeological Survey Report, No. 41

1977 
List of Figures and Tables............ i i Acknowledgments ....................... $i i_{i}$ Introduction .................. 1 Methods ................... 1 Previous Archaeological Research . . . . . . . . 1 Environment, Soils and Geology........... 2 The Survey .................. . . 3 Definitions ............. . . 3 Leon Creek Planning Area . . . . . . . . . 5 5 Rilling Road Planning Area .......... 7 Salado Creek Planning Area . . . . . . . . 9 Treatment Plant Sites............ 17 Conclusions ................ . 17 Recommendations .............. 18 Appendix I. The Confluence Site (Anne A. Fox) . . . . . 22 Appendix II. Descriptive Numerical Analysis of Site Survey Data (Joel D. Gunn and James E. Ivey) . . . 24 References Cited .............. . 35 


\section{LIST OF FIGURES AND TABLES}

Figure

Page

1. Map of Survey Areas . . . . . . . . . . . . 4

2. Archaeological Sites in the Leon Creek Drainage . . . 6

3. Lime Kiln on 01mos Creek (41 BX 367) . . . . . . 10

4. Archaeological Sites in the Salado Creek Drainage . . 13

5. Views of Site $6 \mathrm{C}-2 \ldots \ldots$............ 14

6. Artifacts from the Ashley Site (41 BX 124) . . . . 23

7. Sequence of Analysis for Uniform Coded Site Survey Data.............. 25

8. Proportional Size of Sites Around San Antonio . . . . . 30

9. Cluster Analysis of Component Scores . . . . . . 33

Tables

Page

1. List of Continuous and Upgraded Variables . . . . . 27

2. Varimax Rotated Principal Components Matrix . . . . 31 


\section{INTRODUCTION}

During December of 1976 and January and February of 1977, personnel of the Center for Archaeological Research, The University of Texas at San Antonio (UTSA), carried out archaeological surveys and assessment of more than 11 different drainages and three sewage treatment plant areas around the periphery of the City of San Antonio. This comprised Phase I of a project to assess archaeological resources for preparation of an Environmental Impact Statement for the San Antonio 201 Wastewater Treatment Facilities Project. Phase II of the project will involve archaeological testing where necessary for more accurate assessment of sites recorded in Phase I. Technical aspects of the work have been managed by Radian Corporation as agent for the City of San Antonio. This was done in order to facilitate the preparation of the impact statement by that corporation; regular progress reports to Radian and to the City have been made by the Field Supervisor.

Objectives of the survey were: (1) to determine the presence or absence of archaeological resources within each area that might be affected in any way by construction of sewer lines and related facilities; (2) to record, identify and appraise the relative significance of any resource discovered during the survey; and (3) to make recommendations for a subsequent testing phase, in which a better evaluation could be made of documented cultural resources.

METHODS

Standard archaeological survey procedures were utilized during the course of the work. Survey crews were directed by Center personnel and included both student volunteers and amateur archaeologists familiar with the areas in question. Artifacts were observed and recorded but not collected, except in those instances when the crew felt they were endangered by erosion or by local collectors. Al1 artifacts recovered in these circumstances were returned to the landowner. Sites were recorded on standard survey forms and were assigned temporary field numbers; these were later changed to permanent trinomial numbers reflecting the state (41), the county (BX), and an individual, sequential number for each site assigned by the Texas Archeological Laboratory in Austin. Site locations have been plotted on United States Geological Survey topographic maps (7.5 minute series) at the Center for Archaeological Research, UTSA. The site data are on file at the Center, and duplicate forms have been furnished to the Texas Archeological Research Laboratory, Austin.

The amount of area covered in each drainage varied in width according to the terrain, but in each instance at least the immediate area of the creek and the adjacent terraces on either side were thoroughly examined. Observations on soils, vegetation and geology were made on each valley, and these detailed field notes are on file at the Center. Complete information on each site has also been computerized for future retrieval, reference and analysis.

\section{PREVIOUS ARCHAEOLOGICAL RESEARCH}

At the start of this survey, more than 200 archaeological sites had been recorded for Bexar County at the Texas Archeological Research Laboratory in Austin. However, few efforts have been made to do a countywide archaeological study. 
Woolford (1935) attempted a general analysis based on his personal observations. Fawcett (1972) has published the most complete statement summarizing work done up to that time. Perhaps the most intensive study of the northern Bexar County area has resulted from Center surveys of a series of flood control dams on tributaries of Salado Creek (Hester et al. 1974). Specific studies have also been done in the Northeast Preserve (Fox 1973) and the Walker Ranch on Panther Springs Creek (Scurlock and Hudson 1973; Hudson, Lynn and Scurlock 1974; Hester et al. 1974). A number of sites recorded in the studies cited above were revisited during this survey and the resulting assessments are reported later.

Several types of sites have been recorded in Bexar County. Long-term or traditionally revisited occupation sites (campsites) are characterized by deep deposits containing stone tools, projectile points and the debris resulting from their manufacture and repair. Fragments of animal bones, snails and mussel shells will often be present, along with scattered 1 imestone hearth stones. Temporary camping sites (related to short-term hunting or foodgathering activities) are reflected by a thin scatter of chert flakes, hearth stones and tools in a limited area. Occasionally these temporary campsites occur in sheltered overhangs in the bluffs of northern Bexar County streams. Quarries and workshop areas occur near outcrops of chert, usually in areas of exposed limestone. Such sites are numerous in the northern part of the county. These sites are characterized by numerous nodules of chert and debris resulting from the primary processes of tool manufacture.

The culture history of Bexar County is represented by four major time periods. The Paleo-Indian period (ca. 9200-6000 B.C.) is represented by the occurrence of Folsom, Plainview, Golondrina and other projectile points. The Archaic period (ca. 6000 B.C.-A.D. 1000) is characterized by a sequence of large projectile points (dart points) changing in style through time, and numerous types of stone tools used in a semi-nomadic hunting and gathering lifeway. The Late Prehistoric period (ca. A.D. 1000-1600) saw the introduction of the bow and arrow, represented by small projectile points (arrow points) and bone-tempered plainware pottery. The Historic period is represented by campsites of historic Indian groups, containing trade goods of European manufacture, and sites related to early Spanish and Anglo-European settlement.

\section{ENVIRONMENT, SOILS AND GEOLOGY}

Since these subjects will be treated in detail in the Environmental Impact Statement, they are mentioned here only as they relate to the archaeological record. Vegetational patterns and pertinent soil observations are included in the individual descriptions of survey areas.

A most important geological feature for archaeology in Bexar County is the presence of large outcroppings of chert in the northern part of the county. This was in great demand for the manufacture of tools and projectile points by prehistoric peoples, and may also have been an object of trade throughout the south-central Texas area. Equally important to the early inhabitants were the numerous springs of water which poured forth in abundance throughout the northern 
half of the county, creating such major streams as Leon Creek, Salado Creek, 01 mos Creek and the San Antonio River. These streams and springs attracted game and supported the growth of numerous plants and trees upon which the people depended for subsistence.

The geology of the area has an important effect on the preservation of archaeological sites. We find that abundant water also can mean floods and erosion which can either quickly erode sites or bury them deep (and often undetected) in alluvial terraces. Thus, in the northern parts of the county we find areas of deflated sites, where artifacts of several different time periods have come to rest upon a common surface. We find floodplains where flooding has nearly eliminated all traces of man's presence, and water-worn artifacts deposited downstream from sites which no longer exist. In the southern areas where floods have deposited many feet of alluvium, sites are often deeply buried and streams have changed their channels, isolating prehistoric sites far from areas where they might be expected to exist. As a consequence, few sites have been recorded in southern Bexar County, and little is known as yet about the archaeology of this region.

\section{THE SURVEY}

Site descriptions in the following section are arranged according to area. Bexar County has deen divided into three "Planning Areas," each one encompassing the area serviced by one particular sewage treatment plant. Thus, the areas are referred to as the Leon Creek, Rilling Road and Salado Creek Planning Areas. Individual surveys were carried out along specified, numbered sections referred to here as "Extensions." Fig. I presents a map of the survey areas.

\section{Definitions}

Terminology used in the site descriptions has been kept as simple and nontechnical as possible. Some brief definitions are given below:

Chert, often called flint, is a fine-to-coarse-grained siliceous rock occurring as nodules or seams in limestone.

A core is a chert cobble or nodule from which a flake or flakes have been removed.

A flake is a fragment which has been struck from a core by percussion or removed by pressure in the more refined stages of artifact manufacture.

A biface is a piece of chert which has had flakes removed from two faces. It may be a preform (a manufacturing stage) for a more sophisticated tool, or it may be a finished tool in itself.

A projectile point is an artifact created for specific use on a shaft which is to be propelled in some manner. Larger-sized projectile points are generally supposed to have been used on a dart which was propelled by a spear thrower or atlate, while the smallest ones (often called "bird points") were used on arrows propelled by a bow. The shape and size of projectile points have changed through time so that they are frequently used as a means of dating archaeological deposits. 


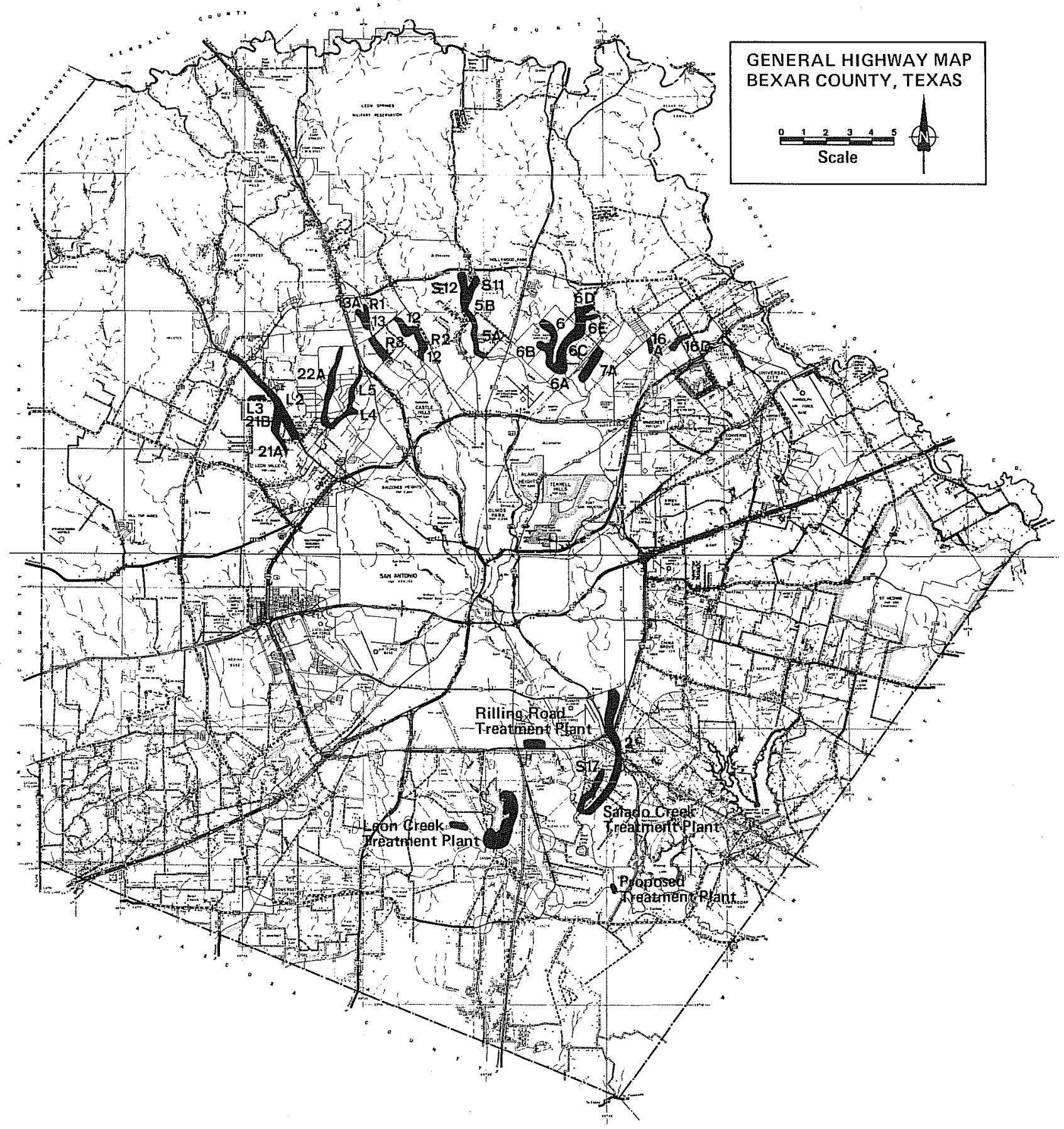

Figure 1. Map of Survey Areas. The areas numbered S17, 21B, etc., are the extensions covered by the survey. Detailed maps and exact site locations have been provided to Radian Corporation, the City of San Antonio, and the Texas Archeological Research Laboratory (Austin). Such information is not published in this report, both for the protection of the sites and as a courtesy to the landowners involved. 
A tool is any object which shows evidence of use, from a simple flake which was casually used and discarded, to a carefully flaked, specialized instrument made for a specific purpose.

\section{Leon Creek Planning Area}

Extension 21A begins at French Creek $1 \mathrm{~km}$ west of Bandera Highway (State Highway 16) and follows the creek northwest to Guilbeau Road for a distance of $25 \mathrm{~km}$. Vegetation along the creek is equally divided between open, previously cultivated fields and dense foliage of chinaberry, scrub oak, persimmon, hickory and live oak. Higher elevations support vegetation of cedar, live oak, prickly pear cactus and various grasses.

Site 21A-1 (41 BX 324) is located 100 m north of the southern end of the section, in open field on the west bank of the creek which appears to have been cultivated intensively in the past. Artifacts observed on the surface included a carefully worked biface, numerous thermally altered chert flakes and other chipping debris scattered over a 50 by $100 \mathrm{~m}$ area. No further work appears warranted.

Extension 21B begins at Guilbeau Road and French Creek and extends north along the creek $3.5 \mathrm{~km}$ to Prue Road. Vegetation is primarily various grasses in open fields, as well as several species of yucca, cacti and hawthorn, with scattered live oaks. Cedar, persimmon and scrub oak grow on the higher terraces. A housing development is located at the upper end of this section.

Site 21B-1 (41 BX 370) contains numerous projectile points and scattered flaking debris over a 51 by $200 \mathrm{~m}$ area in a large cultivated field on the west bank of French Creek (see Fig. 2). Over 300 chert flakes and fragments were observed on the surface, along with many tools. Twenty-three projectile points and fragments were recorded, primarily dating from the Archaic period. Testing is highly recommended for this site.

Site 21B-2 (41 BX 325) is located approximately $150 \mathrm{~m}$ south of Braun Road, $15 \mathrm{~km}$ west of French Creek, and consists of a scatter of 1 ithic flakes and broken tools over a 75 by $100 \mathrm{~m}$ area in a cultivated field. The site appears to be too disturbed and shallow to warrant further work.

Extension L2 runs parallel to and primarily within the right-of-way of Bandera Highway. No archaeological sites were found on this section.

Extension L3 is located adjacent to and north of Braun Road west of Bandera Road. No archaeological sites were found on this section.

Extension $22 \mathrm{~A}$ begins at Huebner Road and Huebner Creek and follows the creek $5.5 \mathrm{~km}$ to De Zavala Road. The southern two-thirds of the area is characterized by housing along the creek proper and increasing land development, especially along the eastern terraces. In the northern third, Huebner Creek runs through undeveloped ranch land. Vegetation along the margins of the creek consists primarily of cedar elm, live oak and cedar.

Site 22A-1 (41 BX 311) is located on an upland terrace along the 950-foot contour line north of Prue Road on the east side of Huebner Creek. The site covers an 


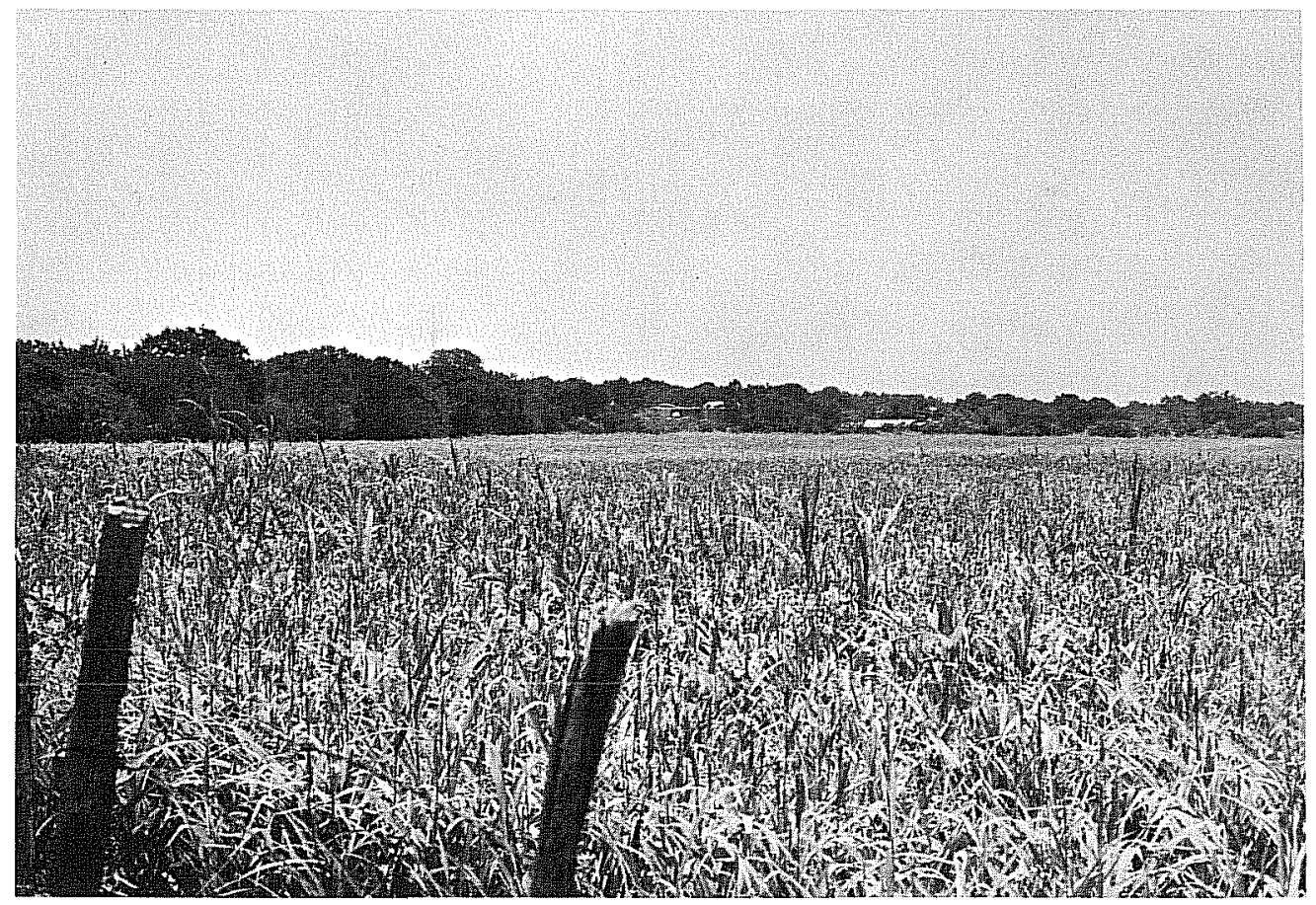

a

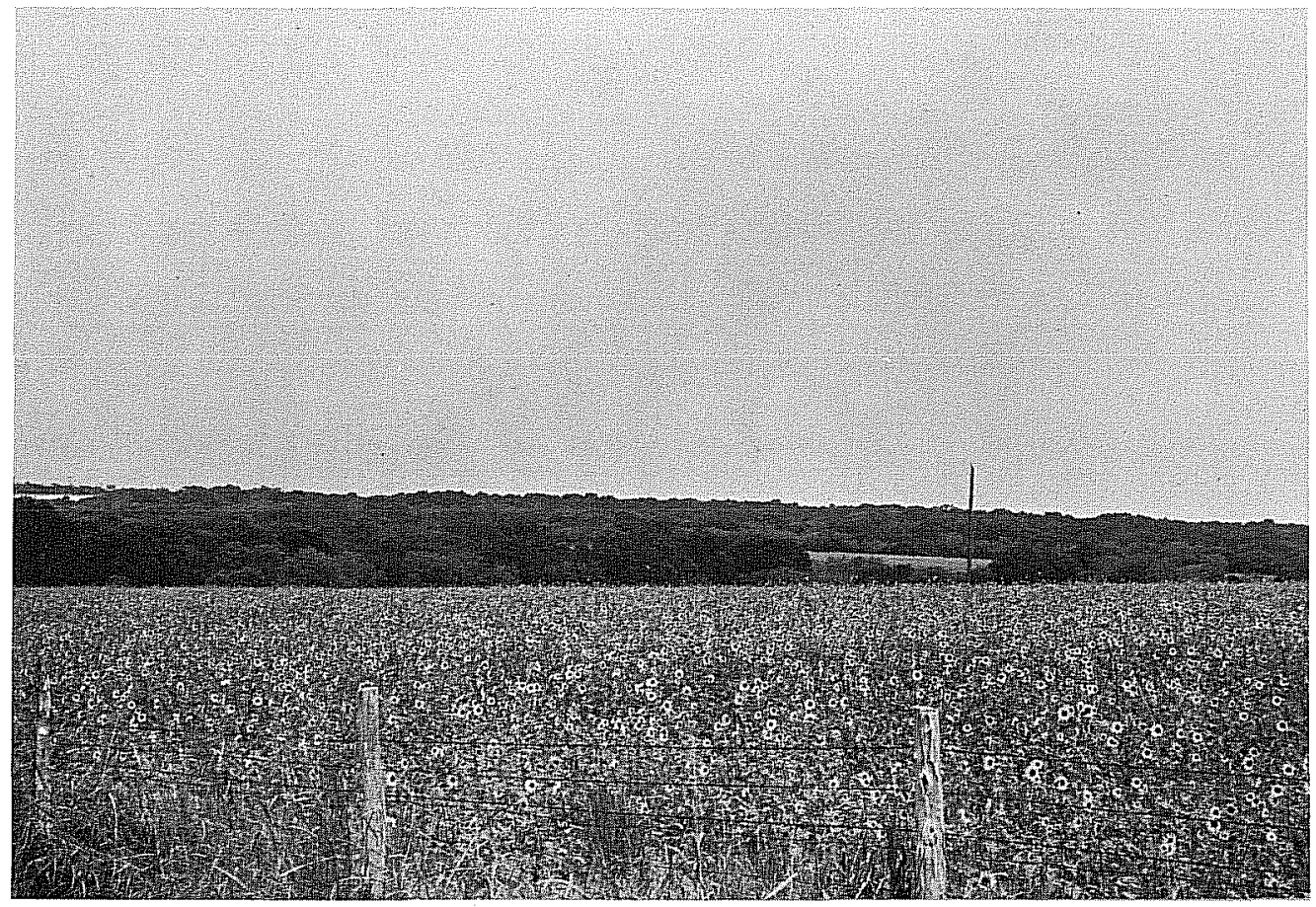

b

Figure 2. Archaeological Sites in the Leon Creek Drainage. a, view of Site 21B-1 from the northwest looking across site toward French Creek; b, view southeast from De Zavala Road toward 22A-4, which is located on the slope in center rear. 
area approximately 50 by $100 \mathrm{~m}$ and consists of a shallow deposit of scattered Tithic debris. No further work is recommended.

Site 22A-2 (41 BX 312) is located on a terrace to the west of Huebner Creek $10 \mathrm{~m}$ north of Prue Road. This site is southwest of and across the creek from 22A-1. Cedar, oak and low brush cover the area, and erosion is evident. Several chert cores and thin bifaces were observed, along with a thin scatter of 1ithic debris. No further work is recommended.

Site 22A-3 (41 BX 313) is located $100 \mathrm{~m}$ southwest of White Bonnet Road between the road and the creek. It consists of a stone house ruin and a collection of dressed stone blocks which appear to be stockpiled, probably from another site. Inquiry should be made to determine if the site has any historical significance.

Site 22A-4 (41 BX 314), on the east side of Huebner Creek $0.5 \mathrm{~km}$ south of De Zavala Road, consists of a 15 by $20 \mathrm{~m}$ area containing a concentration of chert tools and 1ithic debris. The site appears to have some depth, and further testing should be done to determine its potential importance.

Extension L4 begins at the same point as $22 \mathrm{~A}$ and extends to the east, south of Huebner Road and across Babcock to end at Hamilton Wolfe Road. A large portion of the southwestern section of this survey runs through marshy ground with low terraces sloping gently to the creek. Vegetation is minimal, with low brush and grass along the creek margins. No archaeological sites were found.

Extension L5 begins at a junction with L4 roughly $0.7 \mathrm{~km}$ south of Huebner Road and follows an unnamed creek valley north and northeast to end at IH $410,0.5$ $\mathrm{km}$ south of the old Lockhill School. Development has taken place through the central part of this section, but the northern and southern parts are unimproved. The southern portion is extremely marshy around the creek, with low terraces and little vegetation. North of Huebner Road, the drainage is better, and elm, Tive oak and cedar grow on the terraces.

Site L5-1 (41 BX 375) is located $0.2 \mathrm{~km}$ southeast of Huebner Road beginning at a fence line on Valley Green Road. Numerous cobbles of chert, cores, flakes and other chipping debris litter an area 10 by $100 \mathrm{~m}$ in extent. No further work is recommended at this site.

Site L5-2 (41 BX 316) is a historic site just west of the end of this survey. It consists of a stone- 1 ined well and a section of stone wall whose dating and significance are unknown. Inquiry to determine the history of the site is recommended, since it is near an old 19th-century settlement on the stage road to Boerne and Fredericksburg from San Antonio.

\section{Rilling Road Planning Area}

Extension 12 begins at Lockhi11-Selma Road and 01mos Creek and extends along the creek $1.2 \mathrm{~km}$ to the northwest. The upper portion of the section consists of a high bluff on the west bank, the boundary of a development to the west of the creek. The rest of this section is relatively undisturbed and the creek widens and meanders through low, gently sloping terraces, covered in places by alluvium. Vegetation is live oak, elm and cedar. 
Site 12-1 (41 BX 308) is situated $0.2 \mathrm{~km}$ south of George Road on a 3-m-high terrace on the east bank of the creek. Chert debris is scattered over an area 75 by $700 \mathrm{~m}$ and cores, bifaces and Archaic period projectile points were observed on the surface. The deposit does not appear to have any depth, and further work is not recommended on the site.

Site 12-2 (41 BX 309) is located $0.4 \mathrm{~km}$ northeast of Lockhill-Selma Road, on a low terrace on the west bank of the creek. Numerous chert cobbles and large flakes were observed, indicating quarrying activity. No further work is recommended.

Extension 12A begins at 01 mos Creek on George Road $0.3 \mathrm{~km}$ from Harry Wurzbach Highway and follows the creek northwest for $3.5 \mathrm{~km}$ to De Zavala Road. The southern third of the area on the west bank is being subjected to extensive levelling and grading in preparation for development. The extreme northern portion of the eastern terrace is already developed, with houses and fenced yards along the creek margin. The remaining land has been fenced for grazing for many years. The creek bottom is relatively wide, with low sloping terraces in the southern portions and a steep embankment on alternate sides in the central and northern portions. A natural water hole is located in the central part of the section, and it is about this feature that the aboriginal sites are clustered. Chert cobbles are numerous in outcroppings on the higher terraces and in the stream bed throughout the area, and evidence of prehistoric quarrying operations is extensive. Live oak, cedar elm and cedar are the predominant vegetation, with occasional grassy clearings containing cacti and persimmon.

Site 12A-1 (41 BX 320) is located along a bluff on the east bank of the creek $1.5 \mathrm{~km}$ upstream from George Road along the 900-foot contour line. It consists of an area approximately $25 \mathrm{~m}$ in diameter which is strewn with chert nodules, cores and large flakes and other lithic debris, indicating intensive quarrying activity. No further work is recommended.

Site 12A-2 (41 BX 306) is an occupation site situated on the southwest bank of 01 mos Creek on a high bluff above permanent water $0.7 \mathrm{~km}$ northwest of the junction of Huebner and Lockhill-Selma Roads. Cores, tools and numerous small flakes and other lithic debris are present on the surface over an area $25 \mathrm{~m}$ in diameter. No further work is recommended.

Site 12A-3 (41 BX 307) was found in the sides of a backhoe pit which had been dug into alluvial soil on the west bank of the creek $0.3 \mathrm{~km}$ downstream from $12 \mathrm{~A}-2$. Flakes of all sizes were eroding from the wall of the pit. Additional testing is recommended to determine the extent of this site.

Site 12A-4 (41 BX 310) is located on the northern terrace of a westward bend in the creek $1.3 \mathrm{~km}$ south of De Zavala Road. It consists of an area 5 by $75 \mathrm{~m}$ strewn with chert cobbles and outcrops of chert-bearing limestone, cores, tools, large flakes and lithic debris. No further work is recommended at this quarry site, since it is widely known and has been extensively collected by local people.

Extension R2, a sma11 drainage to the northeast of George Road, contained no sites. 
Extension 13 begins at De Zavala Road and tributary of 01mos Creek and extends approximately $0.6 \mathrm{~km}$ northwest between the creek and the Southern Pacific Railroad tracks. Growing subdividions on either side of the valley will soon eliminate most possible locations of archaeological sites in the area. The terrain is gently sloping toward the stream. Cedar and live oak predominate, and there are occasional open grassy areas with clumps of persimmon.

Site 13-1 (41 BX 367) is a mid-19th century lime kiln dug into a low bank on the east side of the creek, $0.5 \mathrm{~km}$ north of De Zavala Road (see Fig. 3). When first recorded, much of the upper portion of the kiln had fallen in, covering the bottom and obscuring the construction of the kiln. With the approval and permission of the property owners, volunteers from the Southern Texas Archeological Association have since excavated the kiln, revealed its structure and various features within it, and fully documented the site before neighborhood vandals could destroy the evidence.

Extension $13 \mathrm{~A}$ begins at the end of Extension 13 and extends $1.2 \mathrm{~km}$ to the northwest along the drainage. No sites were found in this area.

Extensions RT, R3 and R4 were also surveyed and found to contain no archaeological sites.

\section{Salado Creek Planning Area}

Extension $5 \mathrm{~A}$ begins at the intersection of Panther Springs Creek and West Avenue and follows the creek to the northwest to a point just north of Bitters Road, through an area locally known as the Walker Ranch. The terrain in this section consists of gently sloping stream terraces bounded by steep slopes covered with Tive oak and cedar. The northern half is open and grassy with clumps of live oak, mesquite and white brush. The southern half contains dense vegetation of cedar, oak, persimmon, mesquite and thorny brush, particularly just south of a large water hole in the creek and downstream from this point.

A number of archaeological surveys have been carried out in this area, as mentioned above, and over 25 prehistoric sites and one historic site have been recorded here. On a recent survey by personnel of the Center for Archaeological Research (Hester et al. 1974:10-15), the sites of major importance were assessed. Summaries of these assessments are included below. Over 300 acres in the valley are 1isted as "Walker Ranch" in the National Register of Historic Places.

Site 41 BX 228 covers an area of approximately $36,000 \mathrm{~m}^{2}$ on the east bank of the creek, $400 \mathrm{~m}$ upstream from the West Avenue crossing. Test pits in this site along with great quantities of lithic debris, tools, animal bones, mussel shells and other occupational materials. This is considered to be one of the most important archaeological sites in Bexar County. More work here is planned by the Center and the United States Department of Agriculture Soil Conservation Service in the near future.

Site 41 BX 199, on the east side of the creek, is exposed as a scatter of flakes in the bed of a ranch road which crosses the creek southeast of the water hole. 


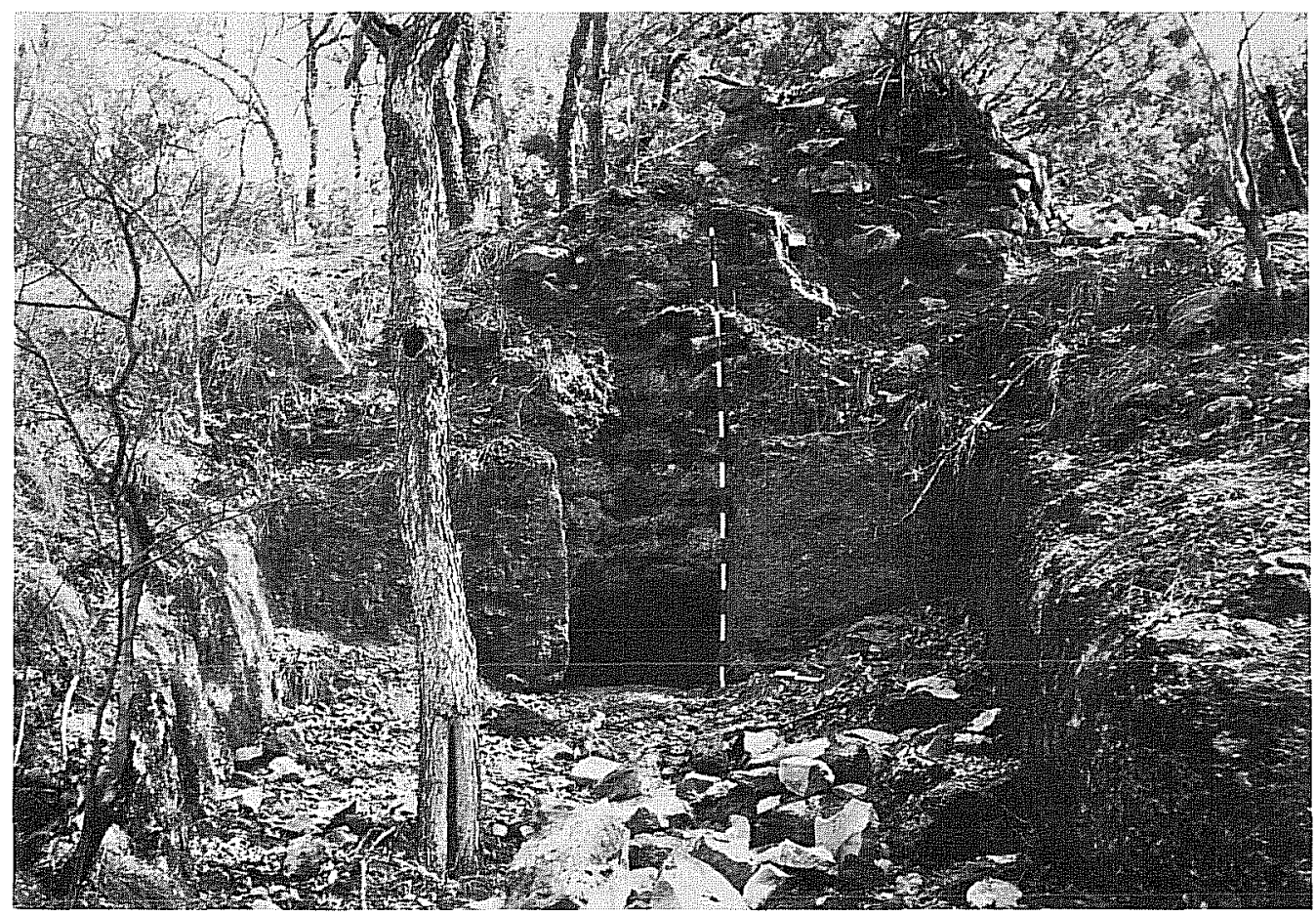

a

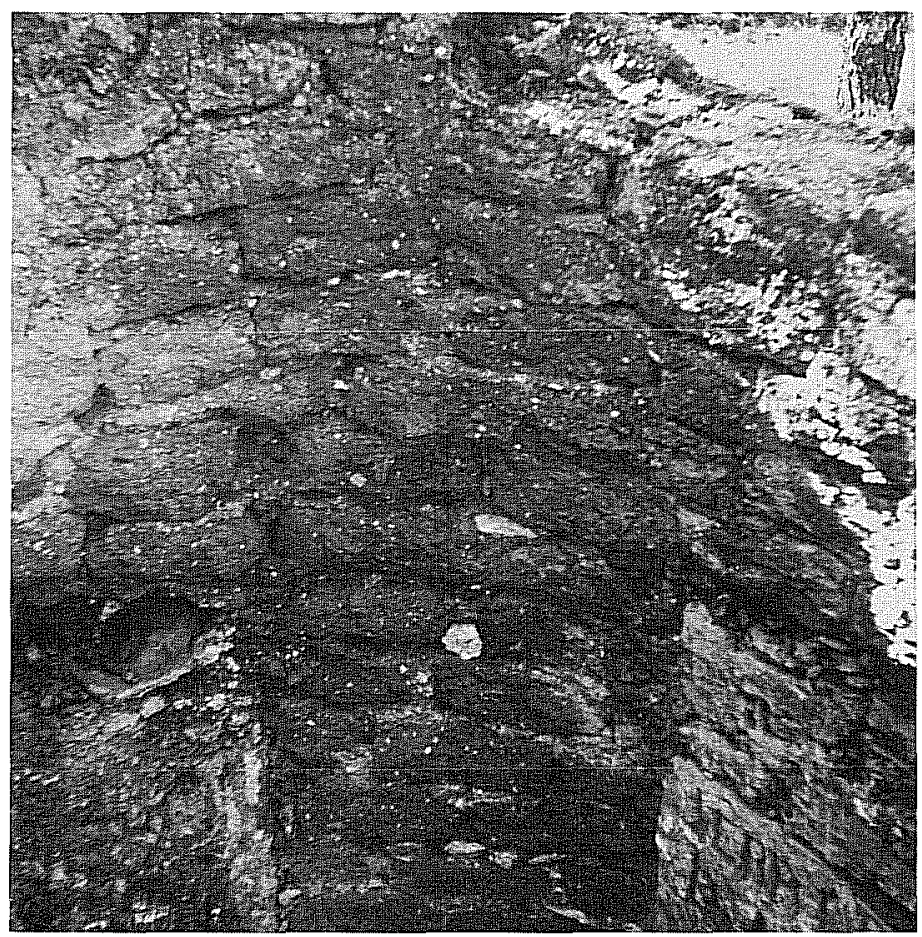

b

Figure 3. Lime Kiln on Olmos creek (41 BX 367). a, view of front of kiln from the creek bed, looking west; $b$, interior construction of the kiln, showing fired adobe brick set in sand and lime mortar. 
Much of the site is probably buried under alluvium. No further work is recommended at present.

Site 41 BX 180 contains a group of stone ruins on the east side of the creek, approximately $1 \mathrm{~km}$ southeast of the water hole. The area is densely overgrown with brush. The ruins consist of several structures grouped within an area bounded by stone walls. There has been speculation that they may have been connected in some way with the 18th century Spanish settlement of San Antonio de Bexar, but no artifactual evidence has been found to support a date earlier than the mid-19th century. A great deal more work is needed at this site, but it is not threatened by the 201 project.

Site 41 BX 184 and 189 (actual1y one site) consist of a heavy concentration of lithic debris and burned limestone fragments extending along the west bank of the creek for $500 \mathrm{~m}$ in a bank $90 \mathrm{~m}$ wide, in a cultivated field. Testing should be done to establish the full extent and buried content of this site.

Site 41 BX 191, 192 and 217 (actually one site) cover an area over 15,000 $\mathrm{m}^{2}$ on the east bank of the creek next to the water hole. A heavy concentration of burned rock, lithic debris, and artifacts lies on the surface. This site should definitely be tested to determine its extent and full potential.

A number of other less important archaeological sites have been recorded along this section of the creek (Hudson, Lynn and Scurlock 1974:Fig. 1). For the most part they appear to represent shallow deposits with no real concentrations. However, if any of these are to be disturbed by pipeline construction, they must be tested for the purpose of better evaluation.

Extension $5 \mathrm{~B}$ begins just northwest of Bitters Road and follows Panther Springs Creek northeast for $1 \mathrm{~km}$. The terrain consists of wide alluvial terraces which have recently been entirely disturbed by a housing development. No sites remain.

Extension $\mathrm{S} 11$ begins $1 \mathrm{~km}$ northwest of Bitters Road on Panther Springs Creek and follows an eastern fork of the creek north to FM 1604. The central portion of this section runs between high bluffs. In the northern section the bluff runs along the western side only, with the Canyon Creek County Club golf course on the gently sloping terrace to the east across the creek. A permanent water hole is located toward the southern end of the canyon. Vegetation consists of live oak and cedar on the terraces and elm and live oak in the creek bottom where it widens and meanders at the southern end of the section. Signs of prehistoric chert quarrying are evident along the entire course of the creek.

Site 517-1 (41 BX 357) is an accumulation of 7ithic debris and tools on the western terrace of the creek to the northeast of the water hole and a smal1 canyon which enters from the east. Testing is recommended on this site, since it lies in an area which will probably be disturbed by any sewer line going up this creek.

Two archaeological sites previously recorded in this valley (Hester et al. 1974:9-10) are summarized below.

Site $517-2$ (41 BX 363) is in a rockshelter in the bluff west of the creek, $0.8 \mathrm{~km}$ due south of FM 1604. An area 3 by $4 \mathrm{~m}$ in the floor of the shelter 
contains burned rock, chert cores and flakes. Since this site has undoubtedly been disturbed in the past, no further work is recommended.

Site S11-3 (41 BX 364) is a burned rock scatter on a terrace east of the creek, $1.25 \mathrm{~m}$ due south of FM 1604. In an area 75 by $180 \mathrm{~m}$ are quantities of burned limestone and lithic debris, adjacent to the southern edge of the 7th tee on the golf course. No further work is recommended unless it is to be disturbed by a sewer line.

Extension S12 is located between the end of 5B and FM 1604 on the west branch of the creek. No archaeological sites were found on this section.

Extension 6 is located on Turkey Creek and runs from a point in the center of McA11 ister Park (formerly the Northeast Preserve) northwest up from the creek to Heimer Road. Through most of this section the creek is bounded by low, gently rolling terraces alternating in open grassy fields, thickets of cedar, persimmon and white brush, and open cedar and live oak forest. Near the upper end a limestone bluff lines the southwest bank for a short distance just below Heimer Road.

Site 6-1 (41 BX 352) consists of a pair of mid-19th century lime kilns in the bluff described above, $0.45 \mathrm{~km}$ southeast of Heimer Road (see Fig. 4). One of the structures is nearly empty except for alluvium and recent trash in the bottom and much of the structure is gone. The other kiln has been completely filled with rubble and trash and may be well preserved because of this protection. The top of the latter is made of cut stone set in mud mortar, and the bottom section was cut into the rocky bluff. Since these are unlikely to be endangered by any sewer line through the area, no further work is recommended.

Extension 6A runs from Bitters Road north $1.2 \mathrm{~km}$ to the center of the park where Extension 6 begins. The area is a wide floodplain of the creek. No archaeological sites are located within this section.

Extension $6 \mathrm{~B}$ runs from the lower end of Extension 6 northwest up a sma 11 drainage for $1.7 \mathrm{~km}$. No sites were found on this section.

Extension 6C follows Mud Creek from its confluence with Turkey Creek $3.5 \mathrm{~km}$ upstream to a point $0.5 \mathrm{~km}$ northeast of Lockhill-Selma Road. Lithic scatter indicative of quarrying activities is evident throughout the area. Cleared fields, some cultivated and some in grass, are found on alluvial terraces on both sides of the creek. Cedar and live oak predominate on the higher terraces, while white oak, cedar elm, hackberry and persimmon are found nearer the creek.

Site 6C-1 (41 BX 353) is an occupation site on the west bank of Mud Creek on Leaping Fawn Drive within the park. A few crude bifaces, cores and flakes were found on either side of the road. Since the area is undoubtedly disturbed by road construction and picked over by park visitors, no further work is recommended here.

Site 6C-2 (41 BX 354) occupies an area 200 by $700 \mathrm{~m}$ on a terrace 6 to $8 \mathrm{~m}$ above the creek bed on the west bank, just north of Lockhi11-Selma Road (see Fig. 5). A swath $5 \mathrm{~m}$ wide has been cleared of brush along the creek bank, revealing a 


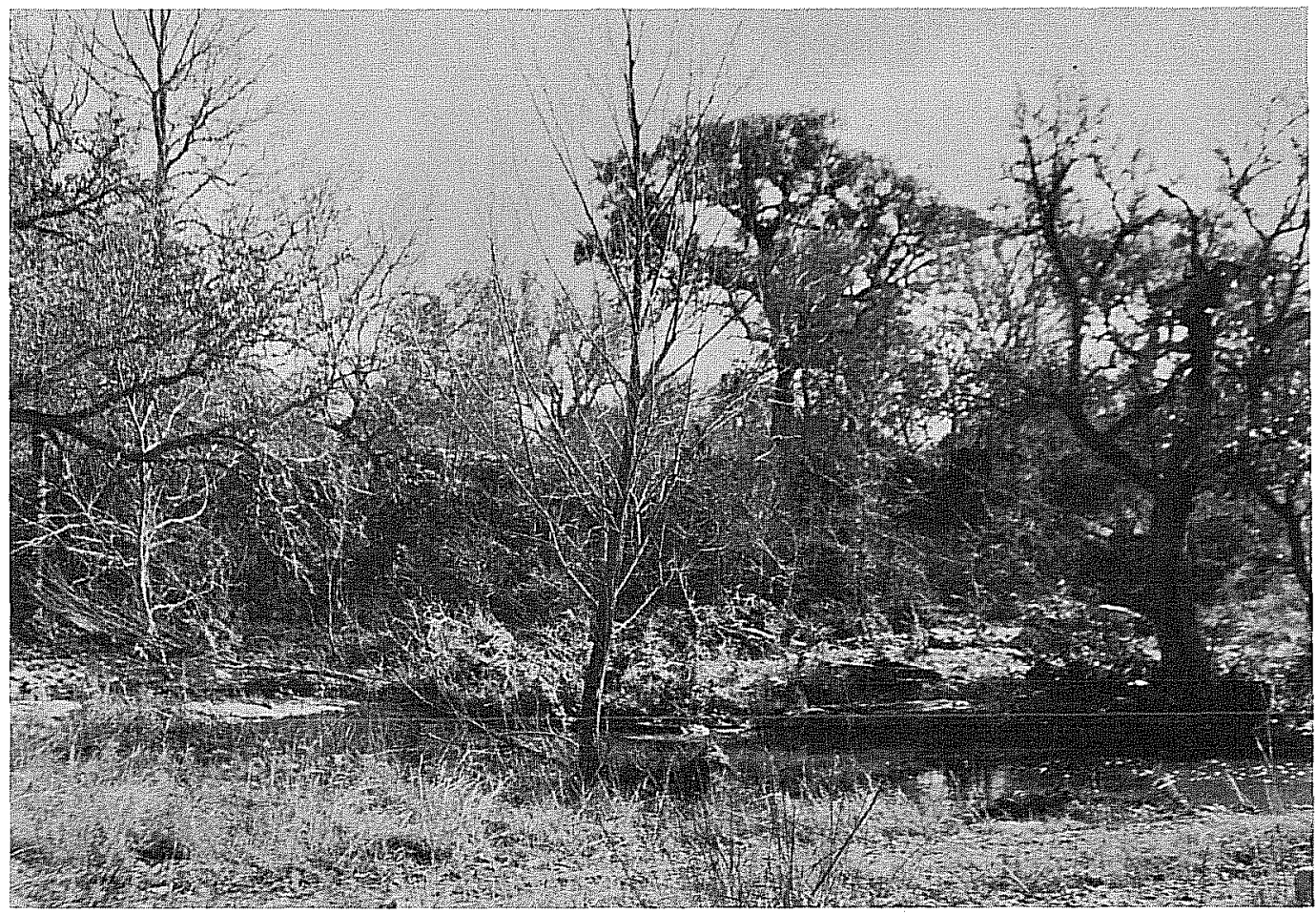

a

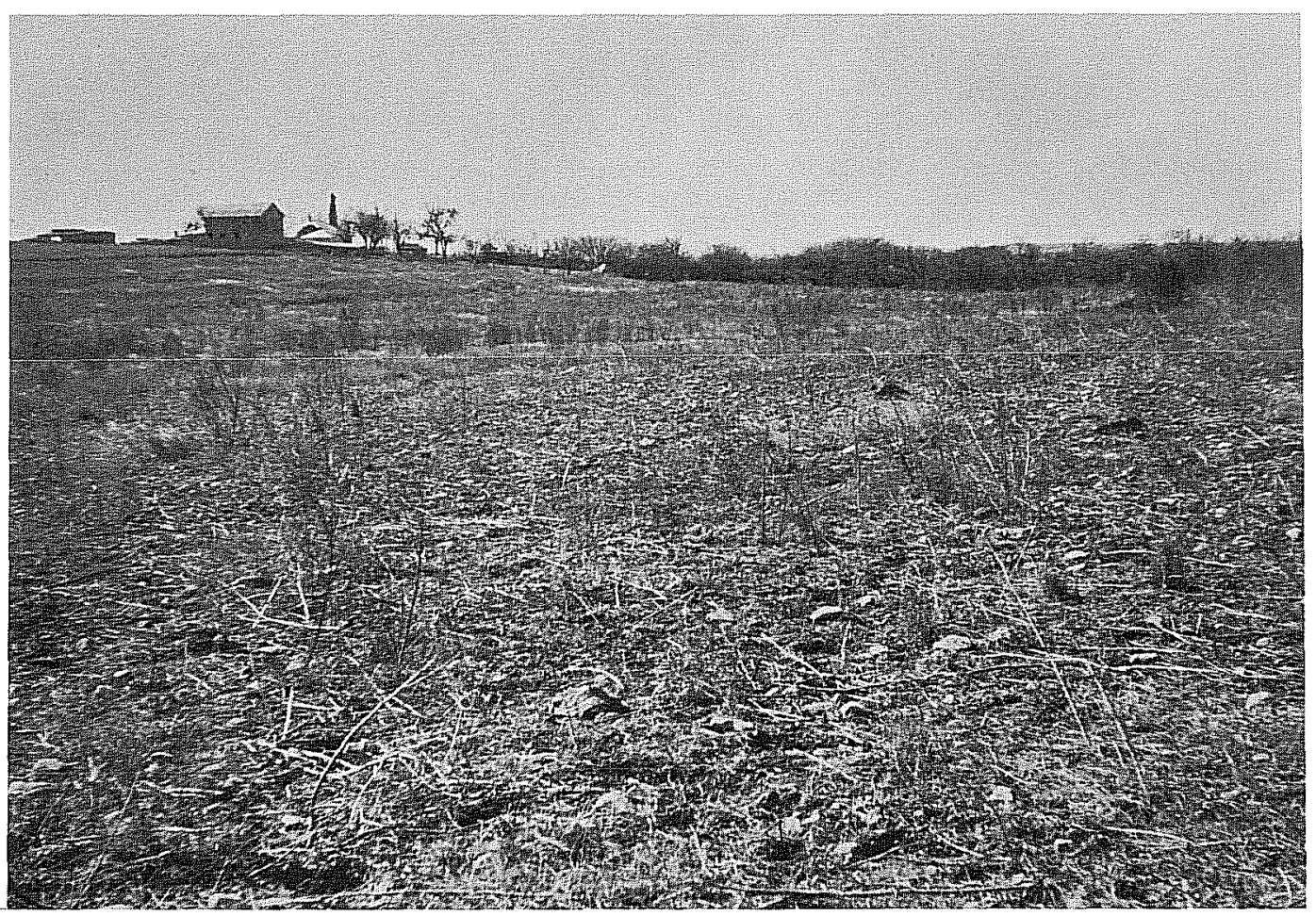

b

Figure 4. Archaeological sites in the Salado creek Drainage, a, view of location of double lime kiln 6-1 from across Turkey Creek, looking south; $b$, view of the general area of Site 16D-1, looking southeast. 


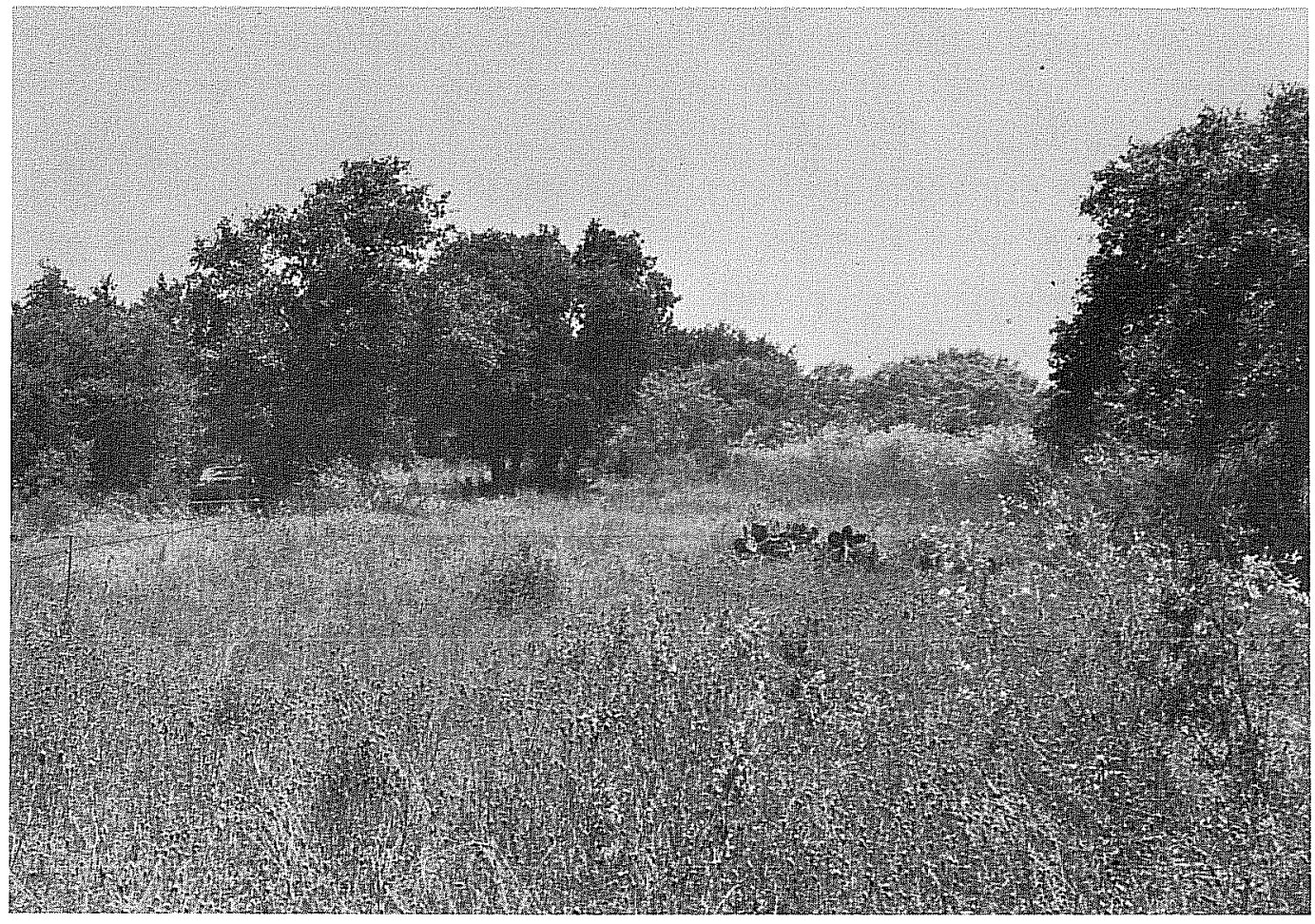

a

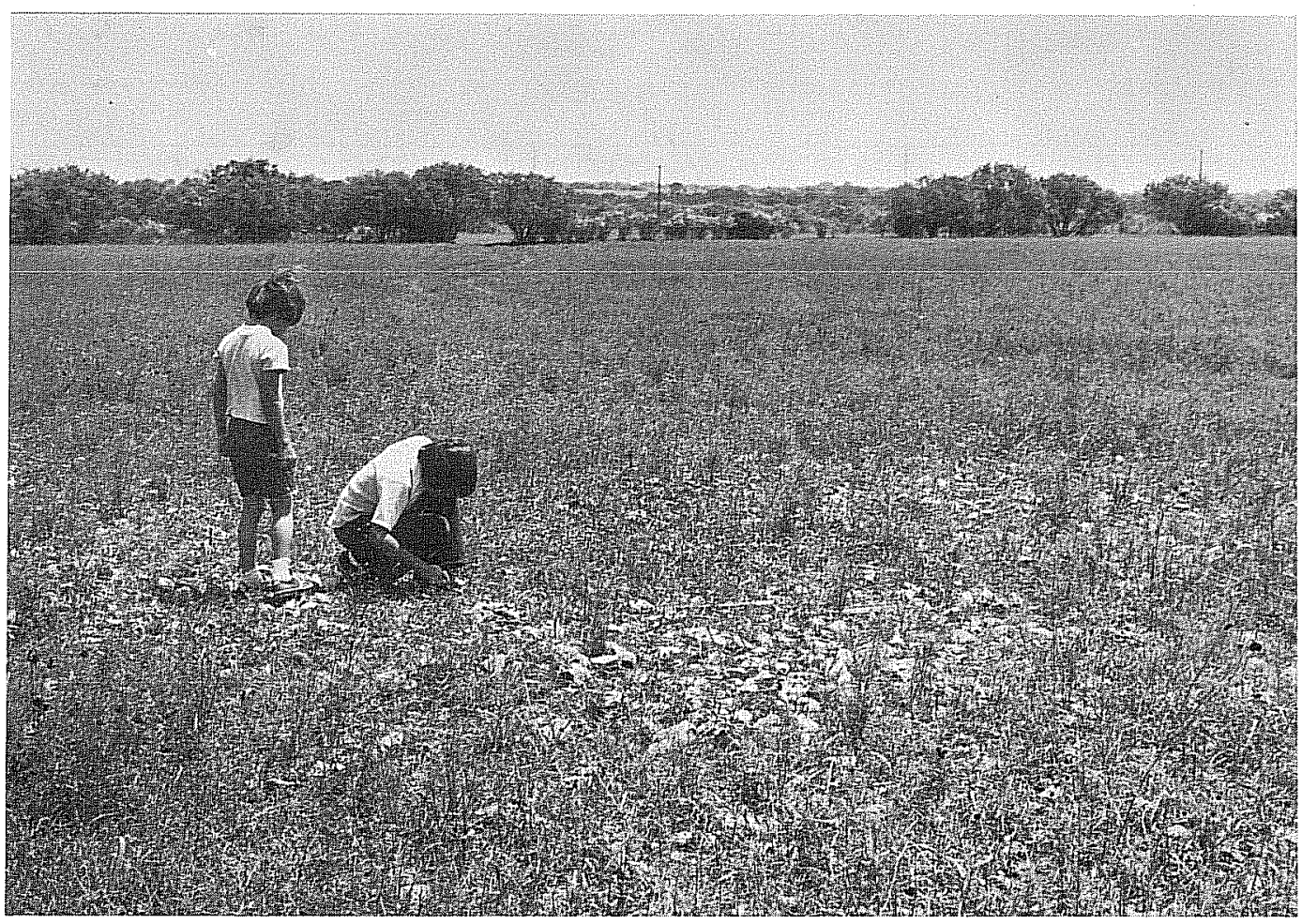

b

Figure 5. Views of Site 6C-2. a, terrain at the north end of the site, looking south; $b$, burned rock midden near the south end of the site, looking southeast. 
mass of lithic debris, cores, tools and projectile points. The area contains at least one burned rock midden. The landowner has allowed two local men to conduct an uncontrolled, non-scientific dig on the site, and their collections have been examined by a member of the survey crew. Out of an area 35 feet in diameter and roughly four inches deep they have screened and removed hundreds of artifacts plus a large collection of lithic debris and animal bone. Projectile points in the collection represent the Archaic and Late Prehistoric periods. It is more than likely that deeper occupations are also present which would be from earlier periods. Intensive testing is recommended on this site to determine its depth and age. The presence of occupation sites and burned rock midden in close context provides the opportunity to study spatial and temporal relationships of these two types of sites.

Extension 6D begins at the end of Extension 6C and follows Mud Creek upstream $2 \mathrm{~km}$ to a point on Bulverde Road, forming the northern boundary of Green Spring Valley subdivision. A high terrace occurs on the west bank immediately north of site $6 \mathrm{C}-1$. The creek meanders through the rest of the valley between low terraces covered with deep alluvium. Vegetation is primarily cedar elm and varieties of oak along the margins of the creek, with cedar and oak on the higher terraces. In the area bounded by the subdivision, extensive levelling has removed any trace of archaeological sites.

Site 6D-1 (41 BX 355) lies in a plowed field on the west side of Mud Creek, and numerous chert cobbles and limestone fragments have been piled near the southeast corner of the field. The surface is strewn with chert flakes, bifaces and tools. As observed in the field, the site covers an area 50 by $100 \mathrm{~m}$, but it may also extend into the area east of the field. There is probably a relationship between this site and site $6 \mathrm{C}-1$, which is less than $150 \mathrm{~m}$ downstream on the same bank, and both should be tested for this possibility.

Extension $6 \mathrm{E}$ runs west to east between Bulverde Road and Mud Creek, from the end of Extension $6 \mathrm{C}$ to the intersection of Jung Road and Bulverde Road. A sewer line has already been laid on the northern bank of the tributary which parallels the eastern third of the section. Vegetation consists of live oak and cedar on the hill to the north upon which Green Spring Valley is built, sporadic mesquite and brush in the cleared pastures along the creek, and live oak and cedar elm in the Mud Creek bottom land.

Site 6E-1 (41 BX 356) is an occupation site 25 by $50 \mathrm{~m}$ on the east bank of a tributary stream which appears to rise suddenly just north of the site and virtually disappears into the level bottom of the site. The landowner reports that water once stood in the creek near the site, and that he dug out the deep pool which today is surrounded by large trees. The geological configuration at this point and the location of a prehistoric occupation site nearby suggests that this has been a water hole fed by local springs since prehistoric times. A number of stone tools were observed along with 1 ithic debris on the surface, and the landowner showed the survey crew a collection of Middle to Late Archaic projectile points which he has found on the site while plowing the field. This site should be tested to determine its full extent and length of aboriginal occupation.

Extension 6F runs just east of U.S. Highway 281 to FM 1604, through the city of Hollywood Park. No archaeological sites remain in this developed area. 
Extension 6G runs from Pipestone Drive to a point $0.3 \mathrm{~km}$ east of U.S. Highway 281. No sites remain intact in this developed area.

Extension $7 \mathrm{~A}$ extends north and south parallel to and $0.4 \mathrm{~km}$ east of Wetmore Road from a point $1 \mathrm{~km}$ south of the MKT Railroad tracks north to Selma Road. The portion immediately north and south of the railroad has been extensively altered by cement company operations, and no archaeological evidence was visible. The upper reaches are open cultivated fields on gently sloping terraces. Vegetation consists of scattered mesquite and live oak around the perimeter of the cultivated fields.

Site 7A-1 (4T BX 377) is a shallow occupation site on a terrace $0.2 \mathrm{~km}$ east of Wetmore Road and $0.8 \mathrm{~km}$ south of Selma Road. It consists of scattered 1 ithic debris, chert cobbles and tools over an area 200 by $300 \mathrm{~m}$. Artifacts observed indicate it was utilized primarily in the Middle Archaic period. No further work is recommended.

Extension 16A follows a shallow drainage parallel to 0 'Connor Road and southeast of Nacogdoches Road. The area is in open fields with mesquite clumps and heavy grass cover.

Site 16A-1 (41 BX 319) consists of a thin scatter of bifacially-worked chert over an undetermined area on both sides of the drainage. No further work is recommended.

Extension 16D lies in a drainage roughiy parallel to the MKT tracks and $1 \mathrm{~km}$ southwest and northeast of Judson Road. The terrain consists of gently sloping terraces which appear to have once been cultivated but are now pasture land.

Site 16D-1 (41 BX 318) is a chert quarrying area of undetermined extent which stretched nearly the whole length of the section on both sides of the drainage (see Fig. 4). Chert nodules, heavy tools and flaking debris are scattered over the area. No further work is recommended.

Extension 2 is located within the Salado Creek and lower Rosillo Creek valleys from the Salado Creek treatment plant to Southeast Military Drive. Topography of the southern half of the section is characterized by terraces into which the creeks have cut channels with steep banks. The banks are composed of sandy alluvial deposits, with occasional stream gravels collecting in washouts. Due to flooding, alluvial deposits far exceed the present banks of the streams, sometimes reaching as far as $150 \mathrm{~m}$ from the present banks. In the northern half of the section the stream banks have a more gradual slope and evidence of flooding and erosion is not as widespread or severe. A large portion of this area has been badly disturbed by highway construction.

Site 2-1 (41 BX 358) is located in a cultivated field on the east bank of Salado Creek approximately $1 \mathrm{~km}$ south of the center of the cloverleaf intersection of Loop 410 and Interstate 37, and directly under a power line.

Evidence consists of 1 ithic debris and burned rock over an undetermined area badly disturbed by cultivation. A few fragments of mid-19th century earthenware were also found, but there is no other indication of a historic site. No further work is recommended. 
Site 2-2 (41 BX 359) consists of an area of 1ithic scatter on the east bank of Salado Creek $250 \mathrm{~m}$ south of Site 2-1 and approximately $70 \mathrm{~m}$ due east of a power line. Evidence included bifaces, cores and lithic debris, which has been disturbed by cultivation. No further work is recommended.

Site 2-3 (41 BX 360) is a badly disturbed occupation site previously observed in the early 1900s by C. D. Orchard. It is located on a terrace between Salado Creek and an old canal. Evidence includes burned rock, chert nodules, cores and flakes. So much bulldozing has been done over the site that there is no reason to attempt further work.

Site 2-4 (41 BX 361) is located on the east bank of Salado Creek $500 \mathrm{~m}$ northwest of the Loop 410 access road. Approximately $1 \mathrm{~m}$ of topsoil has been stripped from the area, removing three-fourths of the site. The remainder of the site (approximately 20 by $200 \mathrm{~m}$ ) contains numerous flakes, tools, bifaces and projectile point fragments. Testing may still reveal important information from this site.

Site 2-5 (41 BX 362) is located on a terrace west of Salado Creek $450 \mathrm{~m}$ south of Military Drive. Flakes, tools, bifaces, cores, snail and mussel shell were observed over a 45 by $60 \mathrm{~m}$ area. Testing is recommended to determine the extent and content of this site.

Extension $\mathrm{S} 17$ is bounded on the east by the southern end of Salado Creek and extends from a point near Center Road to the Southton Sanitorium. No archaeological sites were found within this section.

\section{Treatment Plant Sites}

While the project was in progress, survey crews examined the areas immediately surrounding the Leon Creek, Rilling Road and Salado Creek Treatment Plants, and they also examined a large area to the south and east of Mitchel1 Lake. This work was done at the request of the Public Works Department. The purpose of these surveys was to determine if any cultural resources were present which would be affected by proposed future expansion or construction of these treatment plants. In each case it was determined that no visible historic or prehistoric sites were present. However, because of the location of these plant sites within areas which have been subject to thousands of years of flooding and alluvial deposition, it is entirely possible that buried sites might be present, and would only be revealed when construction is begun. For this reason, we strongly recommend that care be taken to observe and to immediately report any archaeological materials which may be located by such construction activities in the future.

\section{CONCLUSIONS}

This report constitutes a preliminary assessment of archaeological resources in specific areas of Bexar County. At this point in the project, a few tentative conclusions about the archaeology of the county are possible.

The scarcity of projectile points on the surface of sites is not too surprising, given the enthusiasm and number of local collectors of all ages who live in 
the immediate vicinity. Where survey crews were able to examine local collections, it is evident that these materials are present beneath the ground in great numbers in the older and deeper sites.

Tentative, locally held theories about site locations have for the most part been confirmed in the observations of the survey crews. Quarrying operations were widespread wherever the chert outcrops occur. Small campsites were primarily along intermittent streams. Large, deep occupation sites surrounded permanent springs and waterholes in the creeks, and wherever the fortunate coincidence of chert outcrops and permanent water occurred, occupation sites take on the appearance of semi-permanent settlements.

The southern part of the county still withholds its secrets. For this reason, every good indication of a site in this area should be carefully examined.

\section{RECOMMENDATIONS}

Further testing will be necessary on a number of archaeological sites recorded in the survey in order to adequately assess the extent and importance of sites which may be threatened by sewer line construction. In a number of cases landowners have in their possession large collections of artifacts from specific sites on their property. Careful recording and documentation of these collections, necessary for proper assessment of those sites, is recommended for specific sites found in the survey. Historic sites in areas of known early settlements should be more fully documented. This work will comprise Phase II of the present contract. Our assessments and recommendations are presented below:

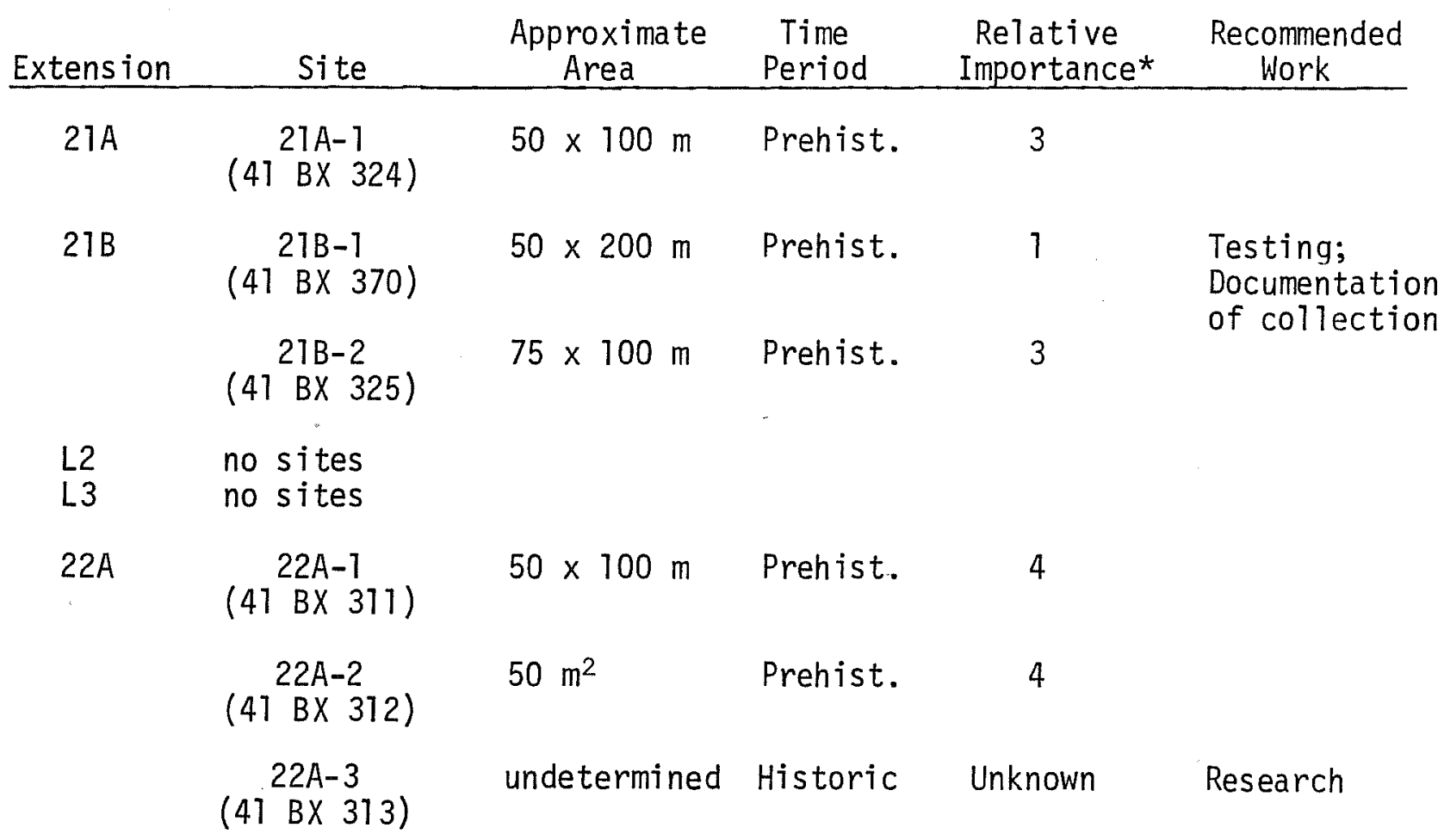




\begin{tabular}{|c|c|c|c|c|c|}
\hline Extension & Site & $\begin{array}{l}\text { Approximate } \\
\text { Area } \\
\end{array}$ & $\begin{array}{l}\text { Time } \\
\text { Period }\end{array}$ & $\begin{array}{l}\text { Relative } \\
\text { Importance* }\end{array}$ & $\begin{array}{c}\text { Recommended } \\
\text { Work }\end{array}$ \\
\hline & $\begin{array}{c}22 A-4 \\
(41 \text { BX 314) }\end{array}$ & $15 \times 20 \mathrm{~m}$ & Prehist. & 2 & Testing \\
\hline L4 & no sites & & & & \\
\hline \multirow[t]{2}{*}{ L5 } & $\begin{array}{c}\text { L5-1 } \\
(41 \stackrel{B X}{3} 315)\end{array}$ & $10 \times 100 \mathrm{~m}$ & Prehist. & 4 & \\
\hline & $\begin{array}{c}\mathrm{L5}-2 \\
(41 \mathrm{BX} 316)\end{array}$ & undetermined & Historic & Unknown & Research \\
\hline \multirow[t]{2}{*}{12} & $\left(41^{12-1} \mathrm{BX} 308\right)$ & $50 \times 100 \mathrm{~m}$ & Prehist. & 3 & \\
\hline & $\begin{array}{c}12-2 \\
\left(41^{B X} 309\right)\end{array}$ & $75 \times 100 \mathrm{~m}$ & Prehist. & 4 & \\
\hline \multirow[t]{4}{*}{$12 \mathrm{~A}$} & $\begin{array}{c}12 A-1 \\
(41 \mathrm{BX} 320)\end{array}$ & $25 \mathrm{~m}^{2}$ & Prehist. & 3 & \\
\hline & $\begin{array}{c}12 A-2 \\
(41 \mathrm{BX} 306)\end{array}$ & $25 \mathrm{~m}^{2}$ & Prehist. & 2 & \\
\hline & $\begin{array}{c}12 A-3 \\
(41 \mathrm{BX} 307)\end{array}$ & undetermined & Prehist. & 2 & Testing \\
\hline & $\begin{array}{c}12 A-4 \\
(41 \text { BX } 310)\end{array}$ & $50 \times 75 \mathrm{~m}$ & Prehist. & 4 & \\
\hline R2 & no sites & & & & \\
\hline 13 & $\begin{array}{c}13-1 \\
\left(41^{13 X} 367\right)\end{array}$ & undetermined & Historic & 1 & \\
\hline $\begin{array}{l}13 \mathrm{~A} \\
\mathrm{R} 1 \\
\mathrm{R} 3 \\
\mathrm{R} 4\end{array}$ & $\begin{array}{l}\text { no sites } \\
\text { no sites } \\
\text { no sites } \\
\text { no sites }\end{array}$ & & & & \\
\hline $\begin{array}{l}\text { S16 } \\
\text { S20 }\end{array}$ & $\begin{array}{l}\text { no sites } \\
\text { no sites }\end{array}$ & & & & \\
\hline S17 & no sites & & & & \\
\hline $5 A$ & $41 B \times 228$ & $36,000 \mathrm{~m}^{2}$ & Prehist. & & \\
\hline & $41 B \times 199$ & undetermined & Prehist. & 2 & \\
\hline
\end{tabular}




\begin{tabular}{|c|c|c|c|c|c|}
\hline Extension & Site & $\begin{array}{l}\text { Approxima te } \\
\text { Area }\end{array}$ & $\begin{array}{l}\text { Time } \\
\text { Period } \\
\end{array}$ & $\begin{array}{l}\text { Relative } \\
\text { Importance* }\end{array}$ & $\begin{array}{c}\text { Recommended } \\
\text { Work }\end{array}$ \\
\hline & $41 \mathrm{BX} 180$ & undetermined & Historic & 1 & \\
\hline & 41 BX 184 & $90 \times 500 \mathrm{~m}$ & Prehist. & 2 & Testing \\
\hline & $\begin{array}{l}41 \mathrm{~B} \times 191, \\
192,217\end{array}$ & $15,000 \mathrm{~m}^{2}$ & Prehist. & 1 & Testing \\
\hline $5 B$ & no sites & & & & \\
\hline \multirow[t]{3}{*}{ S11 } & $\begin{array}{c}\text { S11-1 } \\
(41 \mathrm{BX} 357)\end{array}$ & $50 \times 70 \mathrm{~m}$ & Prehist. & 2 & \\
\hline & $\begin{array}{c}511-2 \\
(41 \mathrm{BX} 363)\end{array}$ & $2 \times 3 \mathrm{~m}$ & Prehist. & 3 & \\
\hline & $\begin{array}{c}\text { S11-3 } \\
(41 \mathrm{BX} 364)\end{array}$ & $75 \times 180 \mathrm{~m}$ & Prehist. & 3 & \\
\hline S12 & no sites & & & & \\
\hline 6 & $\left(41^{6-1} \mathrm{BX} 352\right)$ & $10 \times 20 \mathrm{~m}$ & Historic & 1 & \\
\hline $6 \mathrm{~A}$ & no sites & & & & \\
\hline $6 \mathrm{~B}$ & no sites & & & & \\
\hline \multirow[t]{2}{*}{$6 C$} & $\begin{array}{c}6 C-1 \\
(41 \mathrm{BX} 353)\end{array}$ & $10 \times 20 \mathrm{~m}$ & Prehist. & 4 & \\
\hline & $\left(41^{6 C-2} \mathrm{BX} 354\right)$ & $200 \times 650 \mathrm{~m}$ & Prehist. & 1 & $\begin{array}{l}\text { Testing; } \\
\text { Documentation } \\
\text { of collection }\end{array}$ \\
\hline $6 D$ & $\begin{array}{c}6 \mathrm{D}-1 \\
(41 \mathrm{BX} 355)\end{array}$ & $\begin{array}{c}50 \times 100 \mathrm{~m} \\
8\end{array}$ & Prehist. & 2 & Testing \\
\hline $6 E$ & $\left(41^{6 E-1} \mathrm{BX} 356\right)$ & $25 \times 50 \mathrm{~m}$ & Prehist. & 2 & $\begin{array}{l}\text { Testing; } \\
\text { Documentation } \\
\text { of collection }\end{array}$ \\
\hline $6 \mathrm{~F}$ & no sites & & & & \\
\hline $6 G$ & no sites & & & & \\
\hline $7 A$ & $\begin{array}{c}7 A-1 \\
(41 \mathrm{BX} 317)\end{array}$ & $200 \times 300 \mathrm{~m}$ & Prehist. & 3 & \\
\hline
\end{tabular}




\begin{tabular}{|c|c|c|c|c|c|}
\hline Extension & Site & $\begin{array}{c}\text { Approximate } \\
\text { Area }\end{array}$ & $\begin{array}{c}\text { Time } \\
\text { Period } \\
\end{array}$ & $\begin{array}{l}\text { Relative } \\
\text { Importance* }\end{array}$ & Recommended \\
\hline $16 A$ & $\begin{array}{c}16 A-1 \\
(41 \mathrm{BX} 319)\end{array}$ & undetermined & Prehist. & 4 & \\
\hline 160 & $\begin{array}{c}16 D-1 \\
(41 \mathrm{BX} 318)\end{array}$ & undetermined & Prehist. & 3 & \\
\hline \multirow[t]{5}{*}{2} & $\left(\begin{array}{c}2-1 \\
\text { BX 358) }\end{array}\right.$ & undetermined & $\begin{array}{l}\text { Prehist. } \\
\text { Possible } \\
\text { Historic }\end{array}$ & 4 & \\
\hline & $\left(41^{2-2} \mathrm{BX} 359\right)$ & undetermined & Prehist. & 3 & \\
\hline & $\left.\begin{array}{c}2-3 \\
\left(41^{2} \mathrm{BX}\right. \\
360\end{array}\right)$ & $50 \times 60 \mathrm{~m}$ & Prehist. & 3 & \\
\hline & $\left(41^{2-4} \mathrm{BX} 361\right)$ & $90 \times 200 \mathrm{~m}$ & Prehist. & 2 & Testing \\
\hline & $\left(41^{2-5}\right.$ BX 362$)$ & $45 \times 60 \mathrm{~m}$ & Prehist. & 2 & Testing \\
\hline
\end{tabular}

* Rated on a scale of 1 to 4 as follows:

1. A major site of primary importance, National Register caliber.

2. Potentially important, need more information.

3. Established site location, medium importance.

4. Scattered surface indications onty. 
APPENDIX I

THE CONFLUENCE SITE

Anne A. Fox

In July 1977, the Center for Archaeological Research was requested to conduct a preliminary survey of the Ashley property at the confluence of the Medina and San Antonio Rivers, in anticipation of the possible selection of the area for the construction of a new sewage treatment plant. David Brown of the Center staff toured the property with Mr. Marvin Ashley; examined the prehistoric archaeological site, $41 \mathrm{BK} 124$, which had been reported to exist there; and examined much of the area for traces of additional sites. The property was found to contain no surficial evidence of further historic or prehistoric sites. The location and content of the reported site were confirmed, and its extent estimated to approximately 150 by 200 meters. Materials collected from the surface by the owner over the years include the diagnostic artifacts illustrated (Fig. 6). We wish to thank Mr. Ashley for graciously allowing us to photograph his collection for analysis and documentation.

Judging from surficial evidence alone, it can be estimated that the Ashley site was occupied from the Archaic period (ca. 6000 B.C.-A.D. 1000) to sometime in the Late Prehistoric period (ca. A.D. 1000-1600). If the property is selected for construction of a treatment plant, test excavations will be necessary to determine the depth, extent and possible significance of the site before further recommendations can be made for mitigation in advance of construction.

Historical research will also be necessary to determine if any historic structures have existed on the property, particularly in the light of its having been part of an early 18th century Spanish 1and grant to the de la Garza family, important in the history of San Antonio. 

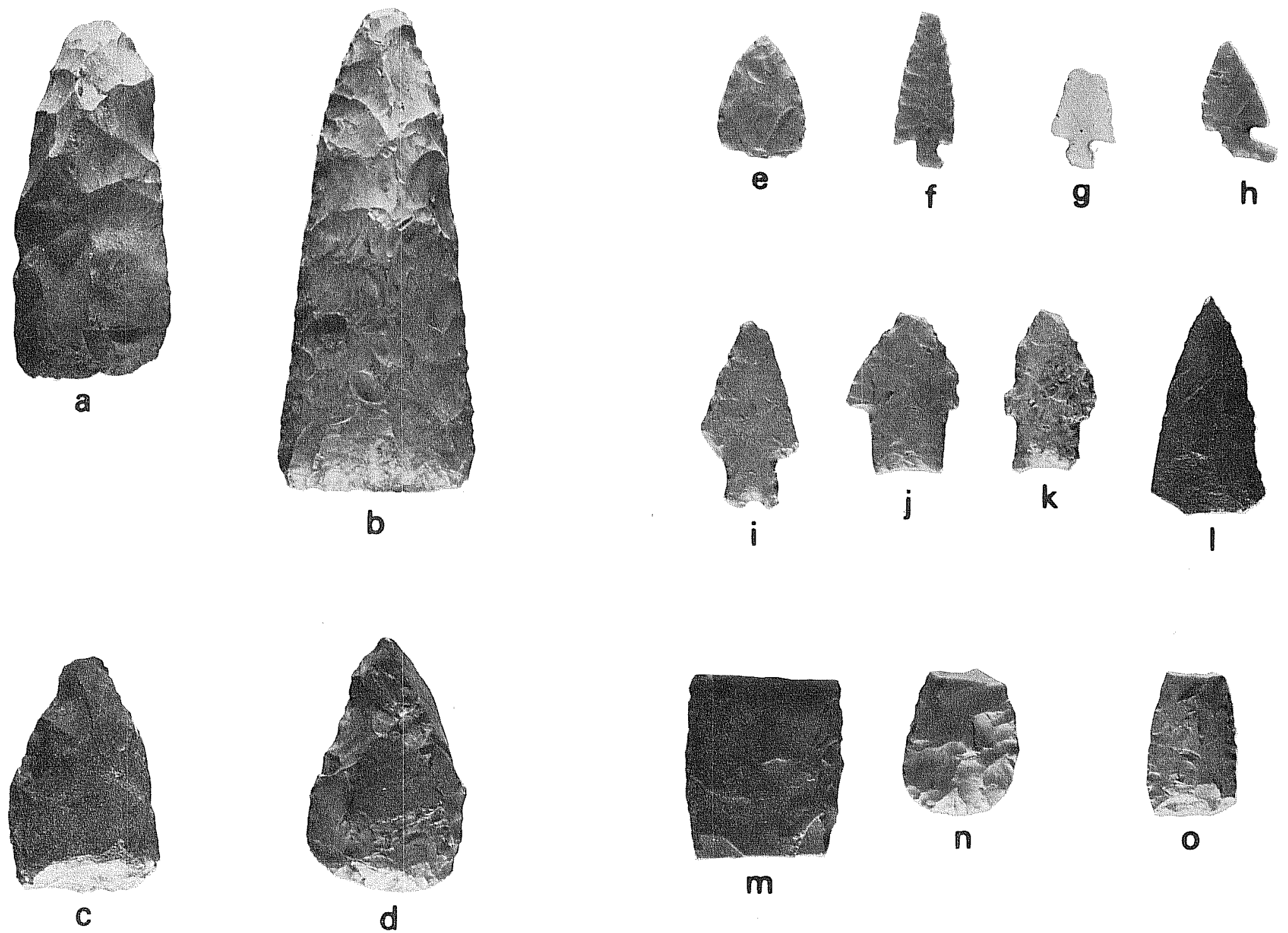

$m$

C

d

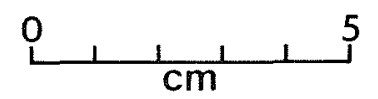

Figure 6. Artifacts from the Ashley Site (41 BX 124). a, Guadalupe too 1; b, Clear Fork too1; c, Guadalupe tool; $d$, bifacial tool; e, arrow point preform; f, Scallorn arrow point; g, Scallorn arrow point; h, Edwards arrow point; $i$, possible Gower dart point; $j$, Bulverde dart point; $k$, Bulverde-like dart point; 1 , Tortugas dart point; m, medial 


\author{
APPENDIX II \\ DESCRIPTIVE NUMERICAL ANALYSIS OF SITE SURVEY DATA \\ Joe1 D. Gunn and James E. Ivey
}

\title{
Introduction
}

The 201 project was the third in a series of survey operations conducted by the Center for Archaeological Research in which data were collected in a manner amenable to computer analysis. Following the previous two projects, a considerable amount of insight was gained in the treatment of survey data, and in the discussion below we review the benefits of that experience.

In 1976, staff members of the Center decided to collect site survey information in a computer analyzable format and to collect a similar and systematic data base from all of the surveys conducted by the Center. In order to give more than descriptive import to this inter-project effort, a problem orientation was selected based on environment systems which would provide what we considered to be the best chance for truly long-term research objectives. The first application of the data coding system was during the Radium Springs project (Hester, ed. 1977), and the second was during the Fort Sam Houston project (Gerstle, Kelly and Assad 1977). Both projects, while providing satisfactory analytical results, were experimental with respect to the data collecting system and the analys is that followed. Our experimentation with those two projects, and developments in the art of numerical analysis of archaeological data in the discipline at large (Christenson and Read 1977), suggested to us the following tactic for the analys is of the data set derived from the 201 survey.

Subsequent to coding and punching of field and laboratory data (Fig. 7), certain variables were upgraded to make the data numerically compatible. Doreain (1972) has shown that variables with a variety of numbers of states (values that the variable can take) cannot be correlated. When the number of states falls below five, correlation with many-state variables will result in undesirable effects; this will be explained later. After few-state variables are upgraded, all of the data are subjected to principal components analys is to determine which of the variables are most important to the cultural and environmental system which produced the sites in the survey area. These system variates are interpreted in verbal form to show how the system functioned. The variates are also output to a second program which clusters the sites; these clusters are then plotted on maps to show relevant cultural geographic distributions. From these clusters of sites and clusters of variables, inferences are drawn as to the nature of the prehistoric cultural system, and recommendations are made as to how it can best be studied.

\section{Data Pretreatment}

Data analysts generally agree that Pearson's R correlation coefficient is the most flexible and reliable measure of association between variables. Doreain (1972), however, has shown that correlations calculated between variables with four or fewer states and variables with five or more states are actually less 


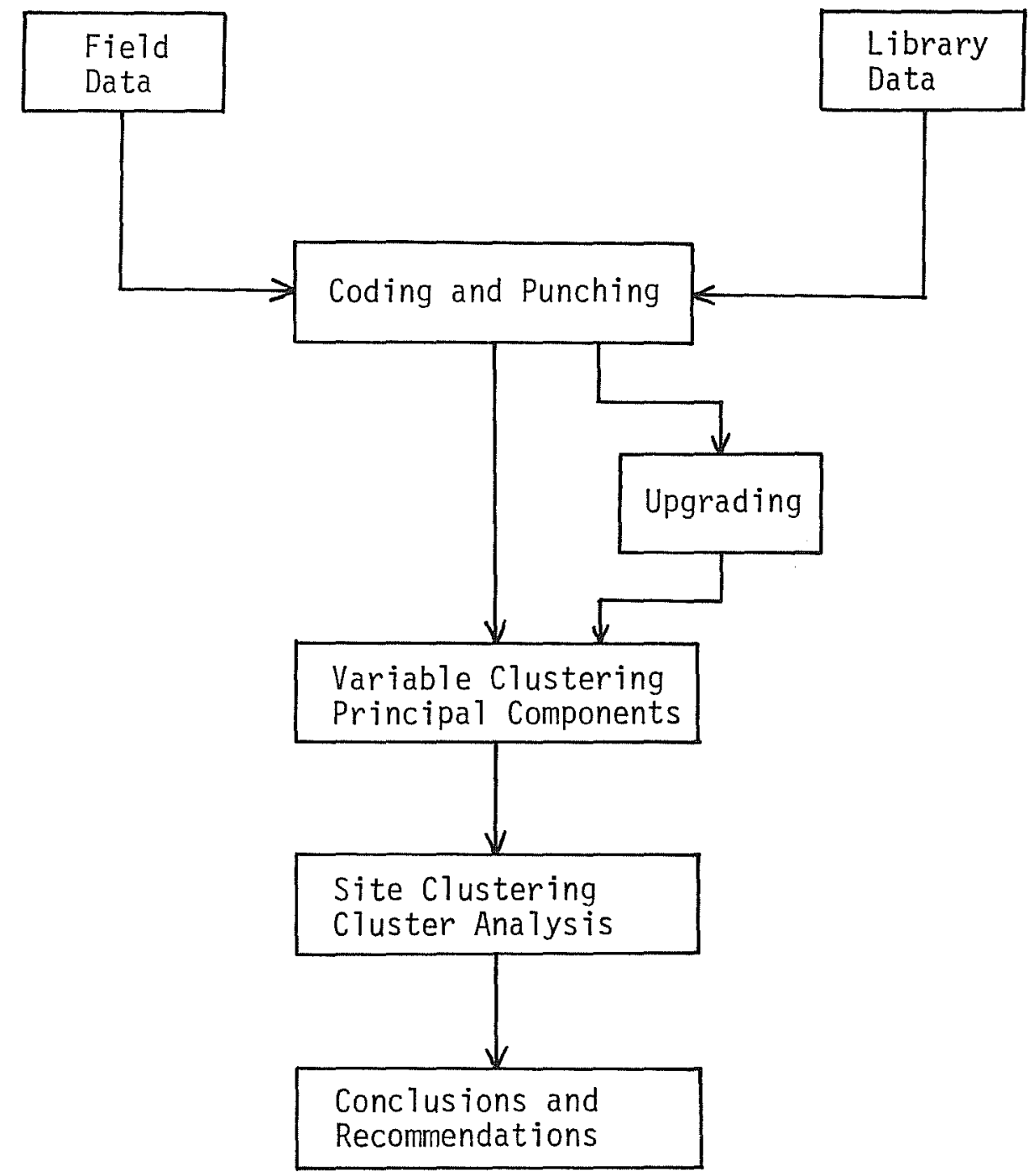

Figure 7. Sequence of Analysis for Uniform Coded Site Survey Data 
than they should be. This is important to our study because we have some variables, such as length of the site, which can take any number of different values, while others are restricted to only a few or even two values. In the context of a principal components analysis this means that many-state variables and few-state variables are automatically and possibly falsely clustered into separate groups.

In order to avoid such a spurious independence, we pretreated the data by taking variables with similar numbers of states and, by the use of principal components, combining or transforming them into fewer variables called components. Components have the characteristic of taking any number of states, as do the rest of the many-state variables. By thus upgrading the number of states of the few-state variables we eliminate the tendency to falsely separate sites that are actually alike.

Two separate transformation runs were made on the data. The first was to combine variables with three and four states. The second was to combine variables with only two states. Only three variables fell into the 3-4 state category: 1ithic frequency, percent of lithic debris with cortex, and the estimate of flake sizes on sites. Principal components ( $\mathrm{Cl}$ in Table 1) combined these into two new variables which accounted for $93.4 \%$ of the variance in the original data. The number and the size of flakes on a site proved to be unrelated and therefore appear separately in the transformed variables. Percent of 7 ithic debris with cortex is correlated with flake size $(\mathrm{Cl}-\mathrm{I})$. This is predictable since decortication flakes are usually larger than interior flakes. There is also a smaller amount of correlation between the number of flakes on a site and the number of flakes with cortex (Cl-II). If we take the flake size/cortex complex to be indicative of chert quarrying and initial chert reduction sites, then quarrying activities are independent of the size of the site as indicated by the number of flakes. Perhaps the implication is that quarries have a wide range of sizes and the size of the sites simply depends on the amount of lithics available to process. One would be inclined to think that "quarrying" consisted of picking up easily available chert wherever it could be found, thus accounting for the many-sized sites. If the prehistoric inhabitants of the area were inclined to return to a favored spot to mine chert, then fewer, larger sites with more debris would result, and as a consequence, there would be a correlation between flake size and number of flakes.

The second transformation was performed on those variables with two states (C2 in Table 1). Some observations were made in two states such as the presence or absence of chronological indicators. Other variables were converted to binary states. In the field, for instance, the number of Archaic points on sites was determined. The number of points found on the surface, however, is not a totally reliable indicator of how much activity there was at an Archaic site because many of the points may have been collected from the sites by relichunters. The presence of Archaic points, then, is good for showing that there were people on a site during the Archaic period, but the number of points found may be misleading as to how much time was spent there. It is a better qualitative indicator than a quantitative one. To accomodate this situation all the counts of tools were converted to presence if any were found or absence if they were not. 
TABLE 1. LIST OF CONTINUOUS AND UPGRADED VARIABLES

1. East

2. North/Elevation

3. Physiography

4. Soil

5. Long Orientation

6. Area

7. Cores

8. Flake Size/Cortex

9. Flake Frequency/ Cortex

10. General Lithics/ Outcrops

11. Chronology

12. Hammerstone/ Perforator

13. Bone/She11/Snail

14. Bone/Historic Pottery

15. Burned Rock
UTM* Coordinate of the site

UTM Coordinate of the site/Elevation of the site, only north used

Location of the site on a physiographic transect

Five-state variable from shallow soil over 1 imestone to thick bottomland alluvium

Orientation of the long axis of the site in degrees east of north

Area of the site in square meters

Number of cores observed

C1-I Component scores

Cl-II Component scores

C2-I Component scores

C2-II Component scores

C2-III Component scores

C2-IV Component scores

C2-V Component scores

C2-VI Component scores

* Universal Transverse Mercator 
Other variables were observed in states that have no linear structure. Lithic outcrops in the area of the site were recorded as being limestone, nodular chert or tabular chert. Since there is no linear relationship between the three states, all chert was lumped into one state and all 1 imestone into another. A binary variable is inherently linear (a straight line is defined by two points) and, therefore, can be entered into the analys is.

The 16 binary variables were transformed into six new variables (Table 1, 1015) which accounted for $76.7 \%$ of the original variance. The most interesting new variable is Component II (C2-II). Sites with Paleo-Indian and Late Prehistoric chronological indicators are negatively correlated with those reported to contain Archaic finds. A study by Gerstle, Kelly and Assad (1977) on the settlement patterns in the Camp Bullis military reservation northwest of San Antonio showed that Paleo-Indian and Late Prehistoric sites were negatively associated. The relationship this chronological variate bears to topography will be examined in the settlement patterns section below. Additionally, scrapers are frequently found at Archaic sites according to C2-II but not at Paleo-Indian or Late Prehistoric sites.

C2-I is a general 1ithics component containing Archaic points, thick and thin bifaces, scrapers and choppers, and all of these are associated with chert outcrops rather than limestone. Curiously, C2-III shows that hammerstones and perforators are associated with chert outcrops, but since it is a different component, these are different sites. One would expect hammerstones to occur with the other lithic residue. Perhaps hammerstones were not used in the manufacture of 1ithic tools, but for other purposes such as crushing of root plants in food preparation.

Component C2-VI shows that the Paleo-Indian diagnostic occurred near a burned rock concentration. Archaic points are positively associated with burned rocks.

C2-IV and C2-V contain sites which evidence snail she11, mussel she11 and bone. There is a strong association between bone and historic pottery (C2-V). The component appears to reflect the vagaries of preservation. As one might expect, prehistoric inhabitants of San Antonio did not arrange their lives with the preservation of organic substances in mind; so there is an unfortunate lack of correlation between distributions of lithics on the one hand, and bone, shel1 and snail remains on the other.

The final list of continuous and upgraded variables is shown in Table 1.

\section{Settlement Pattern}

The general context of the 201 survey was defined by the topography peculiar to the San Antonio area. The center of San Antonio is marked by a cluster of springs and other features attractive to both prehistoric and modern populations. Surrounding the city is a basin-shaped structure. Streams within the basin flow out of the hill country to the north to converge at the central and southern sectors of the city. Streams farther to the north circle around the town to the east and west. All but five of the sites discovered in the survey 
are in the north of the city in an intermediate area between the flat coastal plain to the south and the rise of the hills (Balcones Escarpment) to the north. Most surveying was limited to the floodplains of creeks so the distribution is distinctly biased toward the alluvial microhabitat. Sites in the north are concentrated in a series of 10 floodplain districts. Salado Creek, which is a major watercourse in the area, flows to the east. The surveys were conducted along tributaries north of Salado Creek. The eastern creeks are distinctively more dissected than those to the west. Toward the west the terrain becomes progressively flatter and drainages are of lesser magnitude and importance.

Five sites found to the south of the city are in the sandy and flat coastal plain next to creeks and the San Antonio River.

Analys is of the field and laboratory variables by principal components showed that the sites in the area surveyed by the 201 project were structured according to seven principals which account for $81.7 \%$ of the information in the upgraded data matrix. The rotated components matrix is shown in Table 2. Components I and III indicate the relationship of sites and their cultural content to the cardinal directions. CIII shows that large sites (area) occur in the west of the survey area (Fig. 8). Also, the farther west a site is, the more likely it is to have hammerstones and perforators. CI indicates that, of the sites surveyed, those to the north normally have shallower soils. On these shallower soils, bone associated with historic pottery appears. Also, Paleo-Indian and Late Prehistoric sites appear to the north in contrast to Archaic sites which tend to be further south. Flake frequencies are higher to the south and flakes with cortex are more frequent to the south.

CIV shows a high correlation between the physiographic transect and chronology. Archaic sites tend to be located at the lower and wetter end of the transect, while Paleo-Indian and Late Prehistoric sites are at the higher and drier end. The Paleo-Indian sample consists of only one artifact and can be taken, at best, as being vaguely indicative. The Late Prehistoric sample is more adequate. The pattern is opposite to that reported by Gerstle, Kelly and Assad (1977) for Camp Bullis in the hills to the north of the 201 survey area. It would be very interesting if future research were to reveal that Paleo-Indian and Late Prehistoric settlements were consistently associated and distributed in a pattern complementary to Archaic sites, and that the patterns reversed their relationship to topography between the Coastal Plains and Escarpment Habitat Zones.

CII indicates that cores, larger flakes and flakes with cortex tend not to be associated with clusters of burned rock and Archaic points. CVI shows that within an independent cluster of sites in the sample, higher flake frequencies and flakes with cortex tend to be associated with chert outcrops and shallow soils. Also, high incidences of flakes and flakes with cortex tend to occur in sites whose long orientation is more to the south of east rather than north of east. At first glance this relationship is startlingly incomprehensible. Examination of the pattern of the survey districts, however, shows that it is a logical outgrowth of the radiating pattern of streams along the city's north side. Small flake frequency sites are in the east and the radiating pattern 

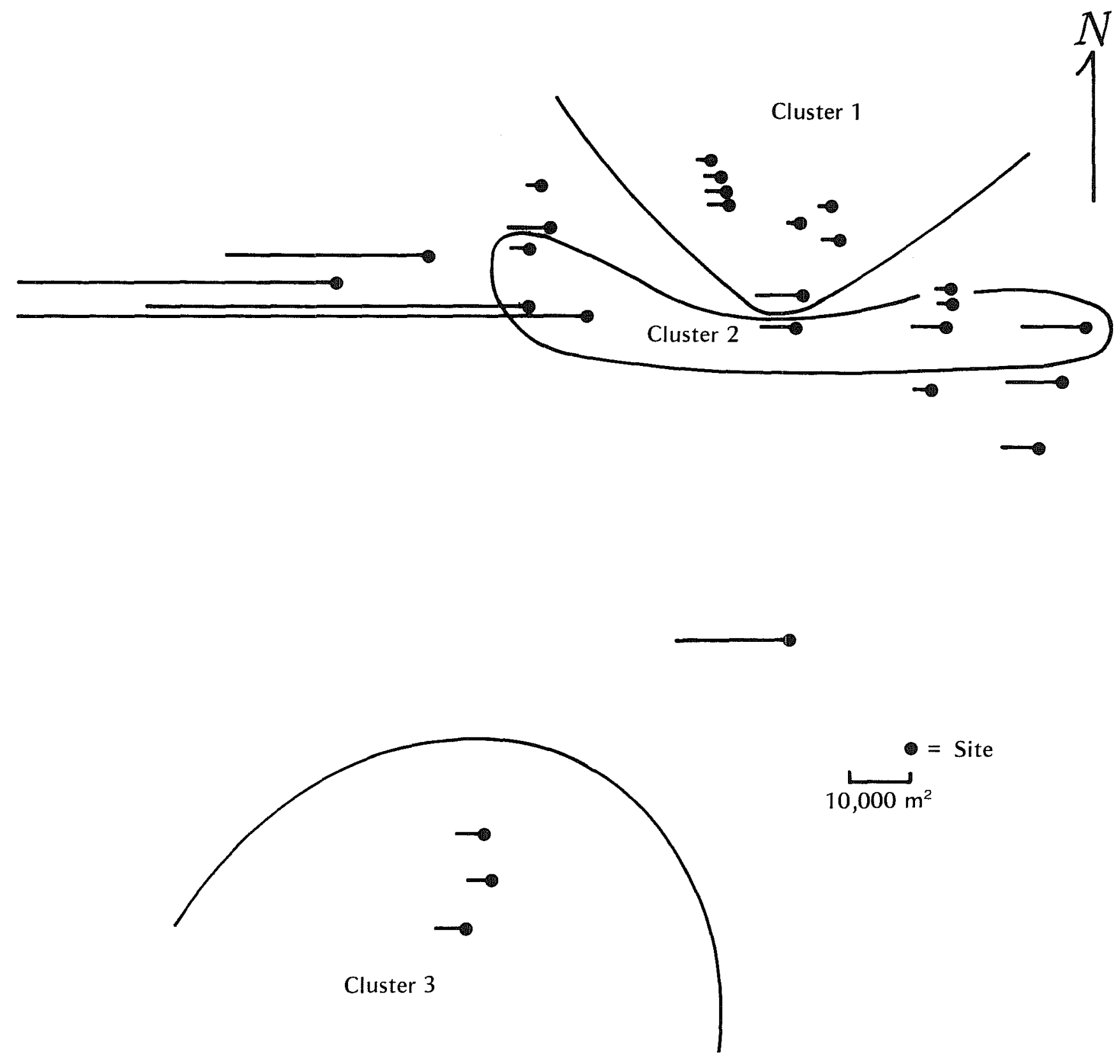

Figure 8. Proportional Size of Sites Around San Antonio. Locations are approximate. 
TABLE 2. VARIMAX ROTATED PRINCIPAL COMPONENTS MATRIX

\begin{tabular}{|c|c|c|c|c|c|c|c|}
\hline & $\mathrm{CI}$ & CII & CIII & CIV & $\mathrm{CV}$ & CVI & CVIII \\
\hline West & & & .7 & & & & \\
\hline North/Elevation & .9 & & & & & & \\
\hline Physiography & & & & .8 & & & \\
\hline Soil & -.7 & & & & & & -.5 \\
\hline Long Orientation & & & & & .9 & & \\
\hline Area & & & .7 & & & & \\
\hline Cores & & .8 & & & & & \\
\hline Flakes/Size Cortex & & .6 & & & & & \\
\hline $\begin{array}{l}\text { Flake Frequency/ } \\
\text { Cortex }\end{array}$ & -.4 & & & & .5 & & .5 \\
\hline $\begin{array}{l}\text { General Lithic/ } \\
\text { Outcrop (Chert) } \\
\end{array}$ & & & & & & & .7 \\
\hline $\begin{array}{l}\text { Chronology } \\
\qquad A=-, P \& L=+S=+\end{array}$ & -.4 & & & -.5 & & & \\
\hline Hammers tone/Perforator & & & .9 & & & & \\
\hline Bone/Shell/Snail & & & & & & .99 & \\
\hline Bone/Historic Pottery & .8 & & & & & .5 & \\
\hline $\begin{array}{l}\text { Burned Rock/Archaic } \\
\text { Points/Paleo-Indian }\end{array}$ & & -.9 & & & & & \\
\hline Active Variance & .24 & .12 & .12 & .06 & .07 & .08 & .07 \\
\hline
\end{tabular}


of streams causes them to be oriented to the northeast. Larger frequency counts were found in the west where long orientations radiate to south of east.

Component VI is simply the reappearance of the preservation factor. Bone, she11, snail and historic artifacts are preserved in favorable circumstances wherever they may be. The fact that preservation of organic material shows no relationship to soil types probably indicates that conditions are not favorable for bone preservation anywhere in the survey area.

A second run of the analysis was made selecting only those 24 sites to the north of town. For the most part the pattern remained stable and, therefore, at least somewhat reliable.

As a final approach to the 201 data the component scores from the principal components analys is of upgraded data were clustered (BMDP2M, Fig. 9). Euclidian distances were calculated as the basis of forming clusters. Many of the sites appeared as unique elements clustering with no other sites. Three recognizable clusters were formed and they are outlined in Figure 8.

Cluster 1 consisted of nine small sites which were located for the most part along small tributaries north of Salado Creek. Most had burned rock. One subcluster (1a) was bluff-top sites with moderate amounts of lithics. One of these contained the diagnostic Paleo-Indian point. The second subcluster (1b) was located near smal1 tributaries and contained large amounts of lithics.

cluster 2 consisted of four medium-sized sites located on the floodplain of Salado Creek. They were all of moderate to large size, they all contained burned rock, and judging by diagnostic tools they were clearly associated with the Archaic period.

Cluster 3 consisted of four sites. Three were in the coastal plain south of town and one was on the extreme east location on Salado Creek in the northern survey area. They were moderate-sized sites located on stream terraces and all contained burned rock and Archaic diagnostics.

\section{Conclusions}

Because of the nature of the 201 survey, few sites were explored outside the alluvial zones of the drainages encompassed by the project area. This analysis, then, has been essentially a study of floodplain settlement patterns. We can tentatively infer, from the limited data collected during the 201 project, that Archaic peoples concentrated their campsite activities in lower and wetter microhabitats; and they preferred the areas where that microhabitat was most abundant, i.e., to the south of the present city and in the wide valleys of that region. It was in these sites that they manufactured their lithic tools, carried out whatever activities resulted in burned rock scatters or middens, and conducted other everyday tasks. Paleo-Indian and Late Prehistoric groups seem to contrast with Archaic groups in their settlement preferences. 


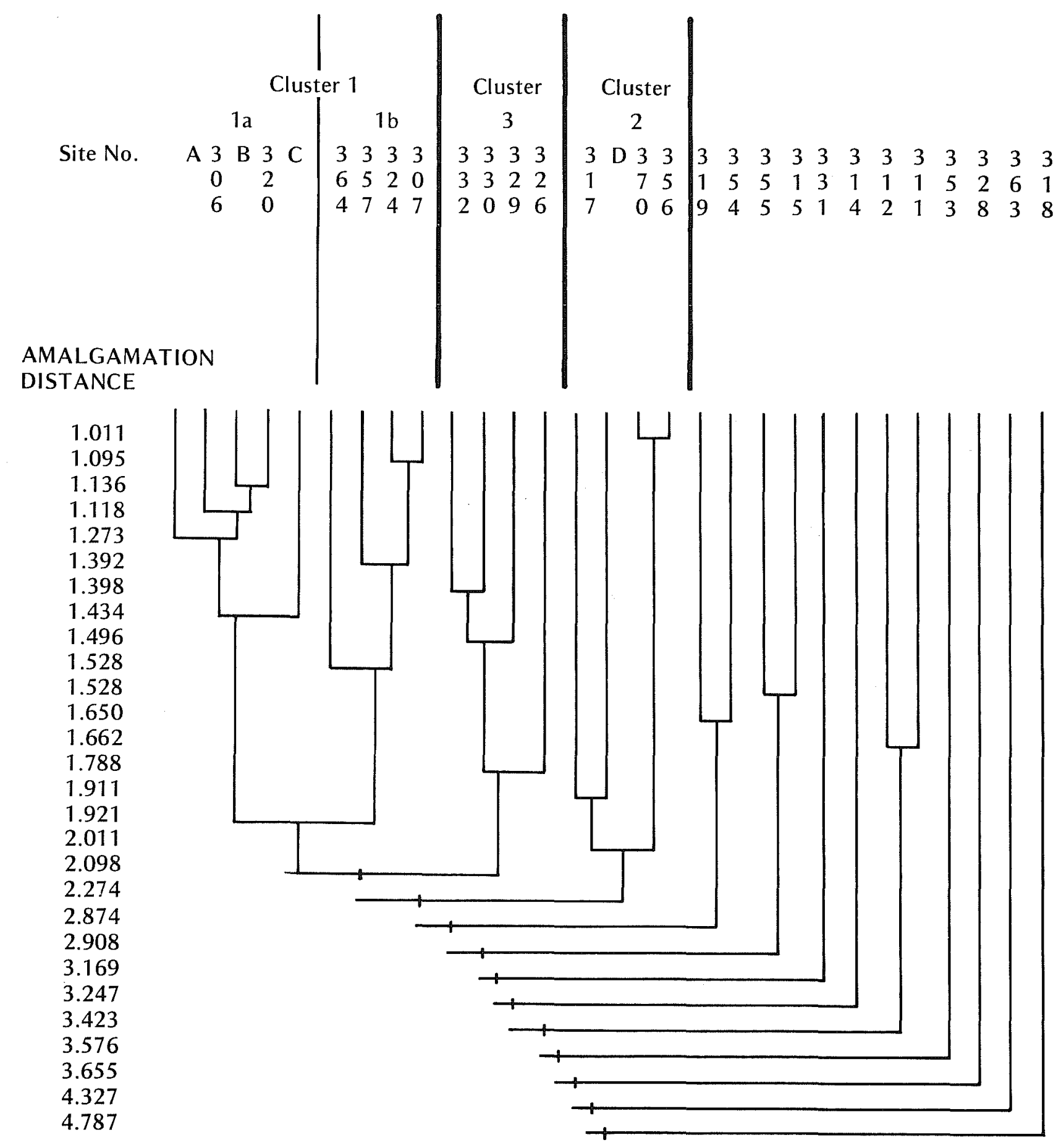

Figure 9. Cluster Analysis of Component Scores. 
They occupied higher valleys, with more shallow soils, in the foothills of the Balcones Escarpment. The subsistence activities which led to this difference of pattern are yet to be determined. Presumably the Archaic populations were harvesting the rich riparian resources such as acorns and deer. Paleo-Indian and Late Prehistoric populations may have been more interested in vantage points related to "big game" hunting (e.g., bison) technology. These are very tentative inferences which must, of course, be tested by further data. 


\section{REFERENCES CITED}

Christenson, Andrew L. and Dwight W. Read

1977 Numerical Taxonomy, R-Mode Factor Analysis and Archaeological Classification. American Antiquity 42(2):163-180.

Doreian, Patrick

1972 Multivariate Analysis and Categorized Data. Quality and Quantity VI(2):253-272. Bologna, Italy.

Fawcett, W. B., Jr.

1972 The Prehistory of Bexar County: A Study of Previous Work in South Central Texas. Bulletin, Lower Plains Archaeological Society 2 (for 1971):23-44.

Fox, A. A.

1973 An Archeological Survey of the Northeast Preserve and J. Street Park, San Antonio, Texas. Report submitted to the Texas Antiquities Committee.

Gerstle, A., T. C. Kelly and C. Assad

1977 The Fort Sam Houston Project: An Archaeological and Historical Assessment. Center for Archaeological Research, The University of Texas at San Antonio, Archaeological Survey Report 40.

Hester, T. R., F. A. Bass, Jr., A. A. Fox, T. C. Kelly, M. F. Chadderdon and E. S. Harris

1974 Archaeological Survey of Areas Proposed for Modification in the Salado Creek Watershed, Bexar County, Texas. Center for Archaeological Research. The University of Texas at San Antonio, Archaeological Survey Report 3.

Hester, T. R. (ed.)

1977 An Archaeological Survey of the Radium Springs Area, Southern New Mexico. Center for Archaeological Research. The University of Texas at San Antonio, Archaeological Survey Report 26.

Hudson, W. R., Jr., W. M. Lynn and D. Scurlock

1974 Walker Ranch, An Archeological Reconnaissance and Excavations in Northern Bexar County, Texas. Texas Historical Commission, office of the State Archeologist Reports 26. 
Scurlock, D. and W. R. Hudson, Jr.

1973 An Archeological Investigation of Walker Ranch. Texas Historical Commission. Austin.

Woolford, S. W.

1935 Types of Archeological Sites in Bexar County, Texas. Witte Museum Archeological Bulletin 4. 